\title{
The Emerging Global Financial Architecture: Tracing and Evaluating New Patterns of the Trilemma Configuration
}

\author{
Joshua Aizenman $^{*}$ \\ UCSC and NBER \\ Menzie D. Chinn ${ }^{* *}$ \\ University of Wisconsin and NBER \\ Hiro Ito $^{\dagger}$ \\ Portland State University
}

Last edited October 7, 2009

Published in

Journal of International Money and Finance, Vol. 29, No. 4, p. 615-641 (2010).

\begin{abstract}
This paper investigates how the trilemma policy mix affects economic performance in developing countries. We find that greater monetary independence can dampen output volatility, while greater exchange rate stability is associated with greater output volatility, which can be mitigated by reserve accumulation; greater monetary autonomy is associated with higher inflation, while greater exchange rate stability and greater financial openness is linked with lower inflation; pursuit of exchange rate stability can increase output volatility when financial development is at an intermediate stage. Greater financial openness, when accompanied by a high level of financial development, reduces output volatility.
\end{abstract}

JEL Classification Nos.: F 15, F 21, F31, F36, F41, O24

Keywords: Impossible trinity; international reserves; financial liberalization; exchange rate; FDI flows.

\footnotetext{
* Aizenman: Department of Economics E2, UCSC, Santa Cruz, CA 95064. Email: jaizen@ucsc.edu.

Corresponding author: Joshua Aizenman, (O) 831-459-4791, (F) 831-459-5077, jaizen@ucsc.edu.

* Chinn: Department of Economics, University of Wisconsin, 1180 Observatory Drive, Madison, WI 53706. Email: mchinn@lafollette.wisc.edu

${ }^{\dagger}$ Ito: Department of Economics, Portland State University, 1721 SW Broadway, Portland, OR 97201. Tel/Fax: 1-503-725-3930/3945. Email: ito@pdx.edu
} 


\section{Introduction}

Against the backdrop of the most severe financial crisis since the Great Depression, the issue of whether the trilemma - the hypothesis that a country can only achieve two, but not all three, goals of monetary independence, exchange rate stability and financial integration - seems rather distant. We argue that, on the contrary, determining the manner in which the trilemma has constrained policy choices is a question that needs to be answered in order to understand how the world economy has arrived at this juncture. East Asian reserve accumulation has been viewed as a contributing factor to the low interest rates blamed by some for the speculative excesses preceding the current financial crisis.

A key message of the trilemma is instrument scarcity - policy makers face a tradeoff, where movement towards increasing the achievement of one trilemma policy goal, such as higher financial integration, induces a drop in the weighted average of the other two variables, i.e., lower exchange rate stability, lower monetary independence, or a combination of the two. ${ }^{1}$ In our previous paper (Aizenman, et al., 2008), we constructed indexes that measure the trilemma goals individually, for both industrialized and developing countries during the period 1970 to 2006. Using these indexes, we showed that the major crises - namely, the collapse of the Bretton Woods system, the debt crisis of 1982, and the Asian crisis of 1997-98 - caused structural breaks in the trilemma configuration. We also examined whether the three policy goals are "binding"; specifically, we tested the linearity of the indexes and confirmed that countries do face a trade-off among the three policy choices. This finding indicates that a change in any one of the trilemma variables induces a change with the opposite sign in the weighted average of the other two. With these results, we conclude that the present turbulence in global financial markets presents a serious challenge to the stability of the current trilemma configuration.

A natural question follows: if policy makers are constrained to choose any two out of the three policy goals, what combination do they prefer? Hence, we test how each of the three policy choices as well as combinations of any two affect the economic outcomes policy makers focus on, such as output and inflation volatility, and medium-term inflation. We center our analysis on developing countries.

Understanding the trilemma choices of developing countries and emerging market countries (EMG) is crucial, since they account for more than half of global GDP, and at times EMGs have grown much faster than industrialized countries. Yet, these countries are also characterized by higher volatility of terms of trade, greater exposure to commodity price shocks, and limited financial depth. These vulnerabilities suggest that the cost of suboptimal trilemma policy choices is more significant for developing countries than for industrialized ones.

\footnotetext{
${ }^{1}$ See Obstfeld, Shambaugh, and Taylor (2005) for further discussion and references dealing with the trilemma.
} 
Moreover, the greater variation in the experiences of developing countries should help in more precisely identifying the impact of trilemma choices on economic performance.

We find that EMGs have moved more towards greater exchange rate flexibility than have non-EMGs, while simultaneously holding much higher levels of international reserves as a buffer. In addition, they have also moved towards greater financial integration and lower monetary independence. In short, EMGs have converged to a sort of middle ground, measured by all three indexes. In contrast, non-EMGs as a group have not exhibited such convergence. While the degree of exchange rate stability declined from the early 1970s to the early 1990s, it increased during the last fifteen years. Of course, this trend might very well reverse in the wake of the current crisis.

Since EMGs have outperformed non-EMGs in terms of average economic growth, the previous observations suggest the superiority of the middle ground configuration. However, without controlling for the macroeconomic environment, one must be cautious about imputing causality, as convergence towards the middle ground may also be the outcome of a successful development strategy. We therefore pursue this question using formal econometric methods, paying close attention to three factors - international reserve (IR) holding, financial development, and the composition of external finance.

First, international reserves have increased rapidly since the Asian crisis of 1997-98, particularly on the part of East Asian and oil exporting countries. China, the world's largest holder of international reserves, currently possesses approximately $\$ 2$ trillion of reserves, accounting for $30 \%$ of the world's total. As of 2006, the top 10 holders of international reserves are developing countries, with the sole exception of Japan. The nine developing countries, including China, Russia, Taiwan, and Korea, hold about 50\% of world international reserves. Against this backdrop, it has been argued that one of the main reasons for the rapid IR accumulation is countries' desire to stabilize exchange rate movement. One perspective holds that countries accumulate massive international reserves in order to achieve some target combination of exchange rate stability, monetary policy autonomy, and financial openness. Consequently, one cannot discuss the issue of the trilemma without incorporating the a role for IR holding.

Second, the ongoing crisis has also made it clear that financial development can be a double-edged sword. While in principle financial development enables a more efficient allocation of capital, it also amplifies shocks to the domestic economy. Hence, the degree of financial development is an integral component of how countries decide to make their trade-offs; China's decision to keep a tight rein on financial liberalization is seen as a manifestation of this 
realization. ${ }^{2}$ Some also argue that countries with newly liberalized financial system tend to be financially fragile (Demirguc-Kent and Detragiache, 1998). Thus, a comprehensive assessment of trilemma policy configurations must account for the level of financial development.

Third, as more countries dismantle capital controls, policy makers in developing countries cannot ignore the effect of capital flows from other countries. Since the type, volume, and direction of capital flows have changed over time (Lane and Milesi-Ferretti, 2006), policy makers have to aim at moving targets. Rapid flow reversals experienced in current crisis also suggests that the trilemma configurations have to be assessed in conjunction with the nature of external financing.

Section 2 briefly outlines the methodology for the construction of our "trilemma indexes". Section 3 conducts a formal analysis of how the policy choices affect output growth volatility, the level of inflation, and the volatility of inflation, centering on developing economies. In Section 4, we extend our empirical investigation and highlight important economic variables related to the current crisis. We first examine the interactive effect of financial development with the trilemma configurations on output volatility. We then examine the effects of external financing on output volatility, inflation volatility, and inflation, focusing on how the trilemma configuration interacts with external financing. In Section 5, we examine the implications of the empirical results for interpreting the ongoing financial crises in selected countries. Concluding thoughts are contained in Section 6.

\section{Development of Trilemma Configurations}

\subsection{Metrics to Measure Trilemma Configurations}

To measure the extent of achievement of the three policy goals of the trilemma we follow Aizenman et al. (2008) in creating the individual indices.

\section{Monetary Independence (MI)}

The extent of monetary independence is defined as the reciprocal of the annual correlation of monthly money market interest rate in home country $j$ and base country $i{ }^{3}$

The index for the extent of monetary independence is calculated as:

\footnotetext{
${ }^{2}$ See Prasad (2008) for the argument that China’s policy of exchange rate stability and closed financial markets is impairing the country's macroeconomic management.

${ }^{3}$ The data are extracted from the IMF's International Financial Statistics (60B..ZF...). For the countries whose money market rates are unavailable or extremely limited, the money market data are supplemented by those from the Bloomberg terminal and also by the deposit rates series from IFS.
} 


$$
M I=1-\frac{\operatorname{corr}\left(i_{i}, i_{j}\right)-(-1)}{1-(-1)}
$$

. By construction, the maximum and minimum values are 1 and 0 , respectively. ${ }^{4}$ Higher values of the index mean greater monetary policy independence. ${ }^{5}$

The base country is defined as the country with which a home country's monetary policy is most closely linked, as in Shambaugh (2004). The base countries are Australia, Belgium, France, Germany, India, Malaysia, South Africa, the U.K., and the U.S. For the countries and years for which Shambaugh's data are available, the base countries from his work are used, and for the others, the base countries are assigned based on IMF's Annual Report on Exchange Arrangements and Exchange Restrictions (AREAER) and CIA Factbook.

\section{Exchange Rate Stability (ERS)}

To measure exchange rate stability, annual standard deviations of the monthly log-change in the exchange rate between the home country and the base country are calculated and included in the following formula to normalize the index between zero and one:

$$
E R S=\frac{0.01}{0.01+\operatorname{stdev}(\Delta(\log (\text { exch_rate }))}
$$

Merely applying this formula might create a downward bias in the index, i.e., exaggerating the "flexibility" of the exchange rate especially when the rate usually follows a narrow band, but is de- or revalued infrequently. ${ }^{6}$ To avoid such downward bias, we also apply a threshold to the exchange rate movement as has been done in the literature. That is, if the rate of monthly change in the exchange rate stayed within $+/-0.33$ percent bands, we define the exchange rate as "fixed" and assign a value of one for the ERS index. Single year pegs are dropped because they are quite

\footnotetext{
${ }^{4}$ The index is smoothed by applying the three-year moving averages encompassing the preceding, concurrent, and following years $(t-1, t, t+1)$ of observations.

${ }^{5}$ Using simple correlation coefficient can be misleading for the case where both the home and base countries are exposed to common external shocks. For example, the interest rates of Canada and the U.S. tend to co-move, but it is not so much that the former's monetary policy is dependent on the latter's as that the two economies are often subject to common external shocks. One way of mitigating this problem is to use the regression coefficient from a regression of the home country's interest on the base country's rate, while controlling for external shocks. However, for countries that have experienced hyperinflation, the regression coefficient turns out to be quite unstable. For the sake of simplicity, we rely on correlation coefficients . We thank Helen Popper for this suggestion.

${ }^{6}$ In such a case, the average of the monthly change in the exchange rate would be so small that even small changes could make the standard deviation big and thereby the ERS value small.
} 
possibly not intentional ones. ${ }^{7}$ Higher values of the index indicate greater exchange rate stability against the currency of the base country.

\section{Financial Openness/Integration (KAOPEN)}

Many measures exist to describe the extent and intensity of capital account controls, although it is generally agreed that such measures fail to capture fully the complexity of realworld capital controls. ${ }^{8}$ In order to maximize the time span and breadth of countries included in our analyses, we use the index of capital account openness, or KAOPEN, by Chinn and Ito (2006, 2008) as our measure of financial openness. KAOPEN is based on information regarding restrictions in the IMF's Annual Report on Exchange Arrangements and Exchange Restrictions (AREAER), and is constructed as the first standardized principal component of the variables indicating the presence of multiple exchange rates, restrictions on current account transactions, restrictions on capital account transactions, and the requirement of the surrender of export proceeds. ${ }^{9}$ Since KAOPEN is based upon reported restrictions, it is necessarily a de jure index of capital account openness (in contrast to de facto measures such as those in Lane and MilesiFerretti (2006)). The choice of a de jure measure of capital account openness is driven by the motivation to look into policy intentions; de facto measures are more susceptible to other macroeconomic effects than solely policy decisions with respect to capital controls. ${ }^{10}$

The Chinn-Ito index is normalized between zero and one. Higher values of this index indicate that a country is more open to cross-border capital transactions. The index is available for 171 countries for the period of 1970 through $2006 .^{11}$

\footnotetext{
7 The choice of the $+/-0.33$ percent bands is based on the $+/-2 \%$ band based on the annual rate, that is often used in the literature. Also, to prevent breaks in the peg status due to one-time realignments, any exchange rate that had a percentage change of zero in eleven out of twelve months is considered fixed. When there are two re/devaluations in three months, then they are considered to be one re/devaluation event, and if the remaining 10 months experience no exchange rate movement, then that year is considered to be the year of fixed exchange rate. This way of defining the threshold for the exchange rate is in line with the one adopted by Shambaugh (2004).

${ }^{8}$ See Chinn and Ito (2008), Edison and Warnock (2001), Edwards (2001), Edison et al. (2002), and Kose et al. (2006) for discussions and comparisons of various measures on capital restrictions.

${ }^{9}$ This index is described in greater detail in Chinn and Ito (2008).

${ }^{10}$ De jure measures of financial openness face their own limitations. As Edwards (1999) discusses, it is often the case that the private sector circumvents capital account restrictions, nullifying the expected effect of regulatory capital controls. Also, IMF-based variables are too aggregated to capture the subtleties of actual capital controls, that is, the direction of capital flows (i.e., inflows or outflows) as well as the type of financial transactions targeted.

${ }^{11}$ The original dataset covers more than 131 countries, but data availability is uneven among the three indexes. $M I$ is available for 171 countries, ERS for 179, and KAOPEN for 177 . Both $M I$
} 


\subsection{Summary Statistics of the Trilemma Indexes}

Figures 1 and 2 provide a summary of the recent history of trilemma configurations for different income and regional country groups over different time periods. In each chart - which we call the "diamond chart," the origin is normalized so as to represent zero monetary independence, a pure float, zero international reserves, and financial autarky. Figure 1 summarizes the trends for industrial countries, industrial countries (excluding the 12 euro countries), emerging market countries, and non-emerging developing countries.

Insert Figure 1

Figure 1 reveals that while both industrialized countries and emerging market countries have moved towards deeper financial integration and less monetary independence, non-emerging market developing countries have only moved marginally toward financial integration, and have not changed their level of monetary independence. Emerging market countries, after giving up some exchange rate stability during the 1980s, have not changed their stance toward exchange rate stability, whereas non-emerging market developing countries have pursued a relatively high level of exchange rate stability. The pursuit of greater financial integration is much more pronounced among industrialized countries than developing countries while emerging market countries have become increasingly more financially open. Interestingly, by the 2000's, emerging market countries stand out from other groups by achieving a relatively balanced combination of the three macroeconomic policy, i.e., middle-range levels of exchange rate stability and financial integration, while not surrendering as much of monetary independence as industrialized countries have. This recent policy combination has been matched by a substantial increase in IR/GDP to levels not observed in any other group. ${ }^{12}$

Figure 2 illustrates trends for emerging market countries in Asia and Latin America (LATAM). Observe that Latin American emerging market economies have liberalized their financial markets rapidly since the 1990s, after some retrenchment during the 1980s, while reducing the extent of monetary independence and maintaining a lower level of exchange rate stability in recent years. Emerging Asian economies stand out by achieving comparable levels of exchange rate stability and financial openness while consistently displaying less monetary

and ERS start in 1960 whereas KAOPEN begins in 1970 . We do not include the United States in our analysis.

${ }^{12}$ To confirm the different trajectories of the trilemma indexes for the groups of EMGs and nonEMG developing countries over the last four decades, we conduct mean-equality tests on the three trilemma indexes and the IR holding ratios between EMGs and non-EMG developing countries. The test results, which are available from the authors upon request, statistically confirm that the path of the trilemma configurations has been different between these two groups of countries. 
independence. This group of economies is most differentiated from the others by their high levels of international reserves holding.

Insert Figure 2

Figure 3 presents the evolution of trilemma indexes for 50 countries for which we can construct a balanced data set (32 of which are developing) during the 1970-2006 time period. For the industrialized countries, financial openness accelerated after the beginning of the 1990s and exchange rate stability rose after the end of the 1990s, reflecting the introduction of the euro in 1999. The extent of monetary independence has experienced a declining trend, especially after the early 1990s. For developing countries, the experience is strikingly different. Up to 1990, exchange rate stability was the most prominent policy choice among the three, despite a long term declining trend. On average, during the 1990s, monetary independence and stable exchange rates became the most pursued policies while financial openness steadily increased during the period. Interestingly, since 2000 exchange rate stability has moderately increased and has become the most pursued macroeconomic policy goal, while monetary independence and financial integration have converged. This development indicates that developing countries have been targeting intermediate levels of both monetary independence and financial openness while maintaining higher levels of exchange rate stability - in other words, leaning against the trilemma - which might explain the reason why some of these economies hold sizable international reserves.

Insert Figure 3

\section{Regression Analyses}

While the above characterization of the trilemma indexes allows us to observe the evolution of policy orientation among countries, it fails to identify countries' motivations for policy changes. Hence, we examine econometrically how various choices regarding the three policies affect final policy goals, namely, output growth stability, low inflation, and inflation stability.

The basic model we estimate is:

$$
y_{i t}=\alpha_{0}+\alpha_{1} T L M_{i t}+\alpha_{2} I R_{i t}+\alpha_{3}\left(T L M_{i t} \times I R_{i t}\right)+X_{i t} \mathrm{~B}+Z_{t} \Gamma+D_{i} \Phi+\varepsilon_{i t}
$$

$y_{i t}$ is the measure of macro policy performance for country $i$ in year $t$, defined as either output volatility measured as the five-year standard deviations of the growth rate of per capita real output (using Penn World Table 6.2); inflation volatility measured by the five-year standard deviation of the monthly rate of inflation; or mean inflation measured as the five-year average of the monthly rate of inflation. $T L M_{i t}$ is a vector of any two of the three trilemma indexes, namely, 
$M I, E R S$, and KAOPEN. ${ }^{13} I R_{i t}$ is the level of international reserves (excluding gold) as a ratio to GDP, and (TLM $\left.M_{i t} \times I R_{i t}\right)$ is an interaction term between the trilemma indexes and the level of international reserves. We are particularly interested in the effect of the interaction terms because we suspect that international reserves might complement or substitute for other policy stances.

$X_{i t}$ is a vector of macroeconomic control variables that includes the variables most used in the literature, namely, relative income (to the U.S. based on PWT per capita real income), its quadratic term, trade openness $(=(E X+I M) / G D P)$, the TOT shock (defined as the five-year standard deviation of trade openness times TOT growth), fiscal procyclicality (measured as the correlations between HP-detrended government spending and HP-detrended real GDP); M2 growth volatility (measured as five-year standard deviations of M2 growth); private credit creation as a ratio to GDP as a measure of financial development; the inflation rate; and inflation volatility. $Z_{t}$ is a vector of global shocks that includes the change in U.S. real interest rate, the world output gap, and relative oil price shocks (measured as the log of the ratio of oil price index to the world's CPI). $D_{i}$ is a set of characteristic dummies that includes a dummy for oil exporting countries and regional dummies. Explanatory variables that persistently appear to be statistically insignificant are dropped from the estimation. $\varepsilon_{i t}$ is an i.i.d. error term.

The data set is organized into five-year panels of 1972-1976, 1977-81, 1982-1986, 198791, 1992-96, 1997-2001, 2002-06. All time-varying variables are constructed as five-year averages. The sample consists of developing countries (LDC) as well as a subgroup of emerging market countries (EMG) ${ }^{14}$ Since inflation volatility, which takes on some extreme values, turned out to be a significant explanatory variable in the regressions for output volatility and the level of inflation, and the inflation level was significant in the regressions for inflation volatility, we need to use an estimation method that handles outliers properly. Hence, we report results from a robust regression method which downweights outliers. ${ }^{15}$ In addition, we remove observations if their values of inflation volatility are greater than a value of 30 or the rate of inflation (as an explanatory variable) is greater than $100 \%$. Furthermore, for the sake of comparability, the same

\footnotetext{
${ }^{13}$ In Aizenman, et al. (2008), we show that these three measures of the trilemma are linearly related. Therefore, it is most appropriate to include two of the indexes simultaneously, rather than individually or all three jointly.

${ }^{14}$ We also conduct a separate set of estimations for a subgroup of developing country commodity exporters (COMMOD-LDC), i.e., developing countries that are either exporters of fuel or those of non-fuel primary products as defined by the World Bank, but do not report the results mainly for the sake of conserving space. The estimation results can be found in the working paper version of this paper. The emerging market countries are defined as the countries classified as either emerging or frontier during the period of 1980-1997 by the International Financial Corporation plus Hong Kong and Singapore.

${ }^{15}$ The robust regression procedure conducts iterative weighted least squares regressions while down-weighting observations that have larger residuals until the coefficients converge.
} 
set of explanatory variables is used for the two samples (excepting regional dummies). Below, we only discuss the results of the regressions involving output volatility and the medium rate of inflation and omit those regarding inflation volatility, mainly because central banks are usually concerned about the former two variables.

\subsection{Estimation of the Basic Model}

\subsubsection{Output Volatility}

The regression results for the estimation on output volatility are shown in Table 1 for developing countries in columns (1) through (6) and emerging market countries in columns (7) through (12), respectively. Various specifications are tested using different combinations of the trilemma indexes as well as their interaction terms. ${ }^{16}$

\section{Insert Table 1}

The model explains well the output volatility for the developing countries subsample. Across different model specifications, the following is true for the sample of developing countries: The higher the level of income is (relative to the U.S.), the lower is output volatility, though the effect is nonlinear. Higher U.S. real interest rates increase output volatility of developing countries (one possible channel for this effect is that a higher U.S. real interest rate affects the debt payment burden of these countries). Greater TOT shocks are associated with higher output volatility, consistent with the findings of Rodrik (1998) and Easterly, Islam and Stiglitz (2001), who argue that volatility in world goods through trade openness can raise output volatility. ${ }^{17}$ Countries with procyclical fiscal policy or significant oil exports tend to experience more output volatility. ${ }^{18}$

\footnotetext{
${ }^{16}$ The dummies for "East Asia and Pacific" and "Sub-Saharan Africa" are included in the model for developing countries, but not reported to conserve space.

${ }^{17}$ The effect of trade openness is found to have insignificant effects for all subgroups of countries and is therefore dropped from the regression. This finding reflects the debate in the literature, in which both positive (i.e., volatility enhancing) and negative (i.e., volatility reducing) effects of trade openness has been evidenced. The volatility enhancing effect in the sense of Easterly et al. (2001) and Rodrik (1998) is captured by the term for (TOT×Trade Openness) volatility. For the volatility reducing effect of trade openness, refer to Calvo et al. (2004), Cavallo (2005, 2007), and Cavallo and Frankel (2004). The impact of trade openness on output volatility also depends on the type of trade, i.e., whether it is inter-industry trade (Krugman, 1993) or intra-industry trade (Razin and Rose, 1994).

${ }^{18}$ Following Acemoglu (2003), we believe institutional development plays a role in reducing output volatility. To measure the level of institutional development, we use the variable LEGAL, which is the first principal component of law and order (LAO), anti-corruption measures (CORRUPT), and bureaucracy quality (BQ). However, it turns out that the LEGAL variable is statistically insignificant and sometimes with the wrong sign (not reported). Given small variations in the time series of the variable, this result is not surprising.
} 
Countries with more developed financial markets tend to experience lower output volatility, a result consistent with the theoretical predictions of Aghion, et al. (1999) and Caballero and Krishnamurthy (2001) as well as the empirical findings of Blankenau, et al. (2001) and Kose et al. (2003). This result indicates that economies with more developed financial markets are able to mitigate output volatility, perhaps by allocating capital more efficiently, lowering the cost of capital, and/or ameliorating information asymmetries (King and Levine, 1993, Rajan and Zingales, 1998, Wurgler, 2000). We revisit this issue below.

Among the trilemma variable indexes, only the monetary independence variable is found to have a significant effect on output volatility: the greater the degree of monetary independence, the less output volatility a country tends to experience. This finding is no surprise, considering that stabilization measures should reduce output volatility, especially with a higher degree of monetary independence. ${ }^{19}$ Mishkin and Schmidt-Hebbel (2007) find that countries that adopt inflation targeting - one form of increasing monetary independence - display lower output volatility, an effect that is greatest for emerging market countries. ${ }^{20}$ This volatility-reducing effect of monetary independence might explain the tendency of developing countries, especially non-emerging market ones, to try to maintain the extent of monetary independence over the years.

Restricting the sample to emerging market developing countries does not affect the results for the macroeconomic variables, but does affect the results for the trilemma indexes. EMG countries with more stable exchange rates tend to experience higher output volatility. This finding is consistent with the results in Edwards and Levy-Yeyati (2003) and Haruka (2007). However, the interaction term is found to have a statistically significant negative effect, suggesting that countries holding high levels of international reserves are able to reduce output volatility. The threshold level of international reserves holding is $21-24 \%$ of GDP. ${ }^{21}$ Thus,

\footnotetext{
${ }^{19}$ This finding can be surprising to some if the concept of monetary independence is taken synonymously to central bank independence because many authors, most typically Alesina and Summers (1993), have found more independent central banks would have no or little at most impact on output variability. However, in this literature, the extent of central bank independence is usually measured by the legal definition of the central bankers and/or the turnover ratios of bank governors, which can bring about different inferences compared to our measure of monetary independence.

${ }^{20}$ The link is not always predicted to be negative theoretically. When monetary authorities react to negative supply shocks, that can amplify the shocks and exacerbate output volatility. Cechetti and Ehrmann (1999) find the positive association between adoption of inflation targeting and output volatility.

${ }^{21}$ In Column (8) of Table 1, $\hat{\alpha}_{1} T L M_{i t}+\hat{\alpha}_{3}\left(T L M_{i t} \times I R_{i t}\right)$ for EMG's ERS is found to be $0.017 E R S_{i t}-0.081\left(E R S_{i t} \times I R_{i t}\right)$ or $\left(0.017-0.081 I R_{i t}\right) E R S_{i t}$. In order for ERS to have a negative impact,
} 
Singapore, a country with a middle level of exchange rate stability (0.50 in the 2002-06 period) and a very high level of international reserves holding (100\% as a ratio of GDP), was able to reduce its output volatility by 2.75-3.2 percentage points. ${ }^{22}$ China, whose exchange rate stability index is as high as 0.97 and whose ratio of reserves holding to GDP is $40 \%$ in 2006, was able to reduce volatility by 1.1-1.5 percentage points. The point estimates on the trilemma variable eoefficients are summarized in Table 3. Further discussion of IR interaction effects are below.

\subsubsection{Medium-run Level of Inflation}

Table 2 shows the results for regressions involving the level of inflation for all developing countries and our sub-sample of emerging market economies. Developing countries with higher inflation volatility, M2 growth volatility, and oil price shocks tend to experience higher inflation. Furthermore, when the world economy is experiencing a boom, developing countries tend to experience higher inflation, presumably reflecting strong demand for goods produced and exported by developing countries.

Insert Table 2

We also find that countries with greater monetary autonomy tend to experience higher inflation. From the perspective that views greater monetary independence as synonymous with a greater central bank independence (as in the time-inconsistency literature), this result is not in accord with priors. ${ }^{23}$ One possible explanation for this finding is that countries with higher levels of monetary independence are more likely to monetize debt. Such countries might be better off (from an inflation standpoint) if they surrendered greater monetary independence, and imported monetary policy from other countries through fixed exchange rate arrangements.

As a matter of fact, in both subsamples, higher exchange rate stability is associated with lower inflation, a result consistent with the literature (e.g. Ghosh et al., 1997). This finding and the previously identified positive association between exchange rate stability and output volatility are in line with the theoretical prediction that establishing stable exchange rates poses a trade-off for policy makers; stable exchange rates can help a country achieve lower inflation by signaling a higher level of credibility and commitment, while at the same time reducing the role

$0.017-0.081 I R_{i t}<0$, and therefore, it must be that $I R_{i t}>0.017 / 0.081=0.210$. Similarly for Model (6),

the threshold can be found to be $I R_{i t}>0.017 / 0.072=0.236$.

${ }^{22}$ See Moreno and Spiegel (1997) for earlier study of trilemma configurations in Singapore.

${ }^{23}$ In other words, more independent central bankers should be able to remove the inflation bias (Kydland-Prescott, 1977 and Barro-Gordon, 1983). 
for exchange rate adjustments as a way of responding to shocks. This is also consistent with the finding of a negative coefficient on monetary independence in the output volatility regressions.

For the LDC group, the interaction term between ERS and international reserves holding is found to have a positive impact on the rate of inflation. Models 2 and 6 in Table 2 show that if the ratio of reserves holding to GDP is greater than $60 \%$ or $65 \%$, respectively, pursuing greater exchange rate stability helps increase the level of inflation. Although these levels of reserves holding are very high, this result means that countries with excess levels of reserves holding will eventually encounter a limit in their efforts to fully sterilize the effects of foreign exchange intervention necessary to maintain exchange rate stability, and thus experience higher inflation. Aizenman and Glick (2009) and Glick and Hutchison (2009) show that China started facing more inflationary pressure in 2007 when it intensively intervened in the foreign exchange market to maintain exchange rate stability. Hence, policy makers cannot fully avoid the trilemma constraint, even when sterilized intervention is feasible.

Last, models with financial openness for both subsamples (columns (3) through (6) and (9) through (12)) show that the more financially open a developing country is, the lower is inflation. Interestingly, in the LDC sample, the more open to trade a country is, the more likely it is to experience lower inflation.

The negative association between "openness" and inflation has been the subject of debate as globalization has proceeded. ${ }^{24}$ Romer (1993), extending the Barro-Gordon (1983) model, verified that the more open to trade a country becomes, the less motivated its monetary authorities are to inflate, suggesting a negative link between trade openness and inflation. Razin and Binyamini (2007) predicted that both trade and financial liberalization will flatten the Phillips curve, so that policy makers will become less responsive to output gaps and more aggressive in fighting inflation. ${ }^{25}$ Here, across different subsamples of developing countries, we present evidence consistent with the negative openness-inflation relationship.

\section{Further Analyses of the Trilemma Configurations on Macro-Performance}

While the above analysis sheds important light on how the trilemma configurations affect macroeconomic performance, other important questions, especially those which have emerged out of the ongoing financial crisis, are not directly addressed. In this section, we investigate the following two issues. First, what is the effect of financial development on output volatility? Second, what is the impact of external financing on output volatility and inflation?

\footnotetext{
${ }^{24}$ Rogoff (2003) argues that globalization contributes to dwindling mark-ups, and therefore, disinflation.

${ }^{25}$ Loungani et al. (2001) provides empirical evidence that countries with greater restrictions on capital mobility face steeper Phillips curves.
} 


\subsection{Interactions between the Trilemma Configurations and Financial Development}

The ongoing financial crisis has illustrated that financial development can have both positive and negative implications. While further financial development might enhance output growth and stability by mitigating information asymmetries, enabling more efficient capital allocation, and allowing for enhanced risk sharing, it can also expose economies to high-risk, financial instruments, thereby amplifying real shocks and/or increasing the likelihood of experiencing boom-burst cycles.

In Table 1, we found that more financial development leads to less output volatility, though the effect is significant only for the LDC subsample. One could ask a related question of how trilemma configurations interact with the level of financial development. There is no question that monetary policy with high levels of authorities' independence, which is found to be volatility-reducing, should work better with more developed financial markets. Exchange rate stability, which can lead to higher output volatility, may be less disruptive if financial markets handle capital allocation more efficiently. Financial liberalization can easily be expected to work hand in hand with financial development to reduce economic volatility.

With these conjectures, we test to see if there is any interaction between the trilemma indexes and financial development, as measured by the ratio of private credit creation to GDP (PCGDP). Unfortunately, the regression results are uninformative: when the output volatility regressions from Table 1 are augmented to include interaction terms between the trilemma indexes and PCGDP, none of these terms are significant. These results (not reported) are not surprising because, as we already mentioned, we suspect that the effect of financial development can be ambiguous.

The drawback of using interaction terms is that we must assume that the effect of PCGDP on the link between the trilemma indexes and output volatility is monotonic; a higher level of PCGDP must either enhance, have no impact on, or reduce the link. Given the lack of statistical significance of the interaction terms, we hypothesize the effect of PCGDP is nonlinear. Consequently, we employ dummies for three different level ranges of PCGDP. ${ }^{26}$ Specifically, we define the variable PCGDP_HI as equal to one for a country if its PCGDP is above the $75^{\text {th }}$ percentile in the distribution of five-year averages of PCGDP within a five-year window, and zero, otherwise. PCGDP_LO takes a value of one if a country's PCGDP is below the $25^{\text {th }}$ percentile, and zero, otherwise. PCGDP_MD takes a value of one if the country's PCGDP lies between the $25^{\text {th }}$ and $75^{\text {th }}$ percentiles in a five-year period. We interact these level category

\footnotetext{
${ }^{26}$ This investigation is motivated by Hnatkovska and Loayza (2005), who examines the nonlinear effect of structural variables, including financial development, on the output volatilitygrowth link.
} 
dummies with the trilemma indexes and include the interaction terms in the output volatility regressions, hoping to capture the nonlinear effect of financial development on the link between the trilemma configurations and output volatility.

Table 3 reports the estimation results only for the PCGDP variable and the interaction terms for the full sample of developing countries (Columns 1-3) and the emerging market countries subsample (Columns 4-6) in order to conserve space. At the bottom of the table, we also report Wald test statistics for tests of the differences in the estimated coefficients of the interaction terms between the trilemma indexes and different PCGDP groups. ${ }^{27}$ Insert Table 3

In Columns (1)-(3), we see that this analysis does not yield any significant results for developing countries. Exchange rate stability contributes to higher output volatility if a country has a medium (or high) level of financial development, while a low level of financial development contributes to reducing output volatility, though none of the estimated coefficients are significant.

For the EMGs (Columns 4-6), the results are more interesting. The estimated coefficient on the term "ERS $\times$ Medium PCGDP" is significant in Columns (4) and (5). In column (5), the coefficient on "ERS $\times$ High PCGDP" is also significant, and the coefficients on both "ERS $\times$ Medium PCGDP" and "ERS $\times$ High PCGDP" are greater than that for "ERS $\times$ Low PCGDP" although the differences are not statistically different. This suggests that for countries with underdeveloped financial markets, higher levels of exchange rate stability might not lead to higher output volatility. Those with medium levels of financial development appear to experience higher output volatility when they pursue a more stable exchange rate. This suggests that countries with newly developed financial markets experience more output volatility when they pursue greater exchange rate stability. Furthermore, in both Columns (4) and (5), the estimated coefficients on the interaction term between ERS and IR are found to be significantly negative. Using these estimates, we can calculate that in order to cancel or lessen the volatilityenhancing effect of ERS, EMGs with medium (or higher) levels of financial development need to hold international reserves amounting to at least 22-25\% of GDP. However, this guideline is not applicable to those with underdeveloped financial markets.

Financial development and financial openness have interesting interactive effects on output volatility as well. While those EMGs with medium or higher levels of financial openness tend to experience less output volatility when they pursue more stable exchange rates, those with underdeveloped financial markets experience greater output volatility. When the coefficient of

\footnotetext{
${ }^{27}$ In this exercise, our focus is to add to the discussion of the impact of financial development on the current crisis. Therefore we focus on the impact of financial development on output volatility, but not on inflation.
} 
“KAOPEN $\times$ Medium PCGDP" and "KAOPEN $\times$ High PCGDP" are compared to that of “KAOPEN $\times$ Low PCGDP," the difference is statistically significant. These results indicate that emerging market economies need highly developed financial markets if they want to reduce output volatility by way of financial liberalization.

These findings suggest that policy management oriented toward exchange rate stability is most likely to exacerbate output volatility when the economy is characterized by a medium level of financial development. Having a higher level of financial openness and financial development can yield a synergistic impact that dampens output volatility. ${ }^{28}$ The worst case scenario is that a country with underdeveloped financial markets can actually exacerbate output volatility with financial liberalization.

\subsection{The Effects of External Financing}

Financial liberalization has increased its pace over the last two decades. This, however, does not mean that countries suddenly became more financially linked with others. In the 1980s, developing countries received external financing in the form of sovereign debt, but the debt crisis spurred many of these countries to shy away from sovereign debt. During the 1990s, the role of FDI became more important and more recent waves of financial liberalization have contributed to a rise in portfolio flows across borders as well.

\subsubsection{Incorporation of External Financing}

We extend our investigation by incorporating the effect of external financing, including net FDI inflows, net portfolio inflows, net 'other' inflows (which mostly consists of bank lending), short-term debt, and total debt service. Net capital flow data were obtained from the IFS, with all components defined as external liabilities (= capital inflows with a positive sign) minus assets (= capital inflows with a negative sign) for each type of flow; negative values mean that a country experiences a net outflow capital. Short-term debt is measured as the ratio of total external debt and total debt service to Gross National Income (GNI). Both variables are retrieved from WDI. Because the debt-related variables are limited, we only deal with a subsample composed of developing countries for which the debt-related variables are available. Also, a dummy for currency crises is included in order to isolate the effect of external financing. ${ }^{29}$

\footnotetext{
${ }^{28}$ See Bekaert et al., (2000, 2001), Henry (2000), Stultz (1999) among others for the link between financial liberalization and the cost of capital. Chinn and Ito (2006) show that financial openness can induce greater financial development.

${ }^{29}$ The currency crisis dummy variable is derived from the conventional exchange rate market pressure (EMP) index pioneered by Eichengreen et al. (1996). The EMP index is defined as a weighted average of monthly changes in the nominal exchange rate, the percentage loss in international reserves, and the nominal interest rate. The weights are inversely related to the
} 
The results are reported in Table 4 for output volatility in columns (1) through (3) and inflation in columns (4) through (6). We present the estimated coefficients only for the variables of interest. ${ }^{30}$ Table 4 shows that the more 'other' capital inflows, i.e., banking lending or more net portfolio inflows, a country receives, the more likely it is to experience higher output volatility, reflecting the fact that countries that experience macroeconomic turmoil often experience an increase in inflows of banking lending or "hot money" such as portfolio investment. FDI inflows appear to contribute marginally to lowering inflation. One possible explanation is that countries choose to stabilize inflation in order to attract FDI. Other types of capital flows do not seem to matter for inflation. Both short-term debt and total debt service are positive and significant contributors to the level of inflation, supporting our previous conjecture that countries tend to monetize their debt especially when their monetary authorities are more independent.

Insert Table 4

Among the trilemma indexes, greater monetary independence continues to be a negative contributor to output volatility, although it is also a positive contributor to the level of inflation. Greater financial openness now has a negative effect on output volatility for this sample of countries, while its negative impact on the level of inflation remains. Higher exchange rate stability continues to dampen the level of inflation, but holding too much international reserves (more than $40 \%$ of GDP) can offset the negative effect and contribute to higher inflation.

\subsubsection{External Financing and Policy Orientation}

Given that the combination of two out of three policy stances is what matters to macro outcomes, when we estimate the effect of external financing, it is important to condition on what kind of policy combination is being pursued by the recipient countries. ${ }^{31}$ The best way for us to do that is to examine the interactive effect between the type of external financing and that of the policy combination. For that purpose, we create dummy variables for the types of policy orientation using the trilemma indexes. Specifically, we first create the first principal components of any two out of the three trilemma indexes. If the composite index of, say, MI and ERS, turns out to be the highest compared to the other two, then we consider that country-year to

pooled variance of changes in each component over the sample of countries, with an adjustment for countries that experienced hyperinflation following Kaminsky and Reinhart (1999). For countries without the necessary data to compute the EMP index, the currency crisis classifications in Glick and Hutchison (2001) and Kaminsky and Reinhart (1999) are used.

${ }^{30}$ Overall, other macroeconomic variables retain the characteristics found in the previous regressions, though they tend to be less statistically significant.

${ }^{31}$ See IMF (2007) for an examination of the relationship between how countries manage capital inflows and subsequent macroeconomic outcomes. 
be the regime that pursues greater MI and ERS (which means less KAOPEN, or "financially closed” policy) and assign a value of one for D_MI_ERS and zero for the other two, D_MI_KAO and D_ERS_KAO. In the results shown in Table 5, the external financing variables are interacted with the dummy for one particular type of policy combination. For example, in columns (1) and (2) of Table 5 we use in the estimation of output volatility the dummy for the policy orientation of greater monetary independence and exchange rate stability (MI_ERS; or “financially closed" policy option) and interact it with the external financing variables. Columns (3) and (4) use the dummy for the policy orientation of greater monetary independence and further financial opening ("more flexible exchange rate" policy), and columns (5) and (6) use that of greater exchange rate stability and further financial opening ("currency union” or currency board). The following six columns report results for regressions involving the level of inflation.

Insert Table 5

For output volatility, we find different types of external financing have different effects on output volatility depending on the policy regime in place. Net FDI inflows, for example, tend to dampen output volatility in general, but raise volatility in a regime pursuing greater monetary independence and more stable exchange rates (i.e., less financial openness). Net portfolio inflows have a positive impact on output volatility, but its volatility-increasing impact is especially high for the countries with the ERS-KAO ("currency union”) regimes, in line with what has been found in the crisis literature. Countries with more flexible exchange rates (or monetary independence and financial openness), on the other hand, may be able to dampen the volatilityincreasing effect, though its effect for this policy orientation is not found to be statistically significant. Positive net inflows of bank lending can be volatility increasing, but that effect can be dampened, although only marginally, if the country adopts a policy combination of exchange rate stability and financial openness.

The greater is debt service, the more likely a country is to experience higher levels of output volatility, especially when the country pursues a combination of greater exchange rate stability and financial openness. This result appears to be consistent with the "original sin" argument; countries that are indebted in a foreign currency and that try to maintain both exchange rate stability and capital account openness often experience sudden capital flow reversal and consequently higher output volatility.

Different types of policy combinations seem to matter only for 'other' (i.e., bank lending) inflows in the estimations for the level of inflation; a net recipient of bank lending flows tends to experience lower inflation if it adopts a policy combination of monetary independence and financial openness, but it could experience higher inflation if it adopts a financially closed 
system. One merit of a country with a currency union-like regime is that it can dampen the inflation pressure of total debt service.

\section{Implications for the Current Crisis and Afterward}

\subsection{IR Holding and the Exchange Rate Regime Interactions}

It has been argued that one of the main causes of the financial crisis of 2008 is the ample liquidity provided by global imbalances; current account surplus countries hoard international reserves in an attempt to stabilize their exchange rates, export liquidity to the global markets, and finance profligacy in the advanced countries, especially the United States. ${ }^{32}$ In the previous subsection, we have seen that countries can reverse the volatility-increasing effect of pursuing greater exchange rate stability if they hold higher levels of international reserves than some threshold (around 20\% of GDP). This might explain why many countries are tempted to hold higher levels of IR. In an attempt to shed further light on the motivations for holding IR, we first examine how IR holding and the exchange rate regime interact with each other.

Figure 4 shows the marginal interactive effects between ERS and IR based on the estimates from Column (8) of Table 1. For presentation purposes, the EMG group of countries is divided into three subgroups (a) an Asian group, (b) a Latin American group, and (c) all other EMG countries. In all the panels of figures, the contours are drawn to present different levels of the effect of ERS on output volatility conditional on the level of IR. The solid horizontal line refers to the threshold of IR at 21\% of GDP, above which higher levels of ERS has a negative impact on output volatility. ${ }^{33}$ For example, the solid contour line above the threshold shows the combinations of ERS and IR that lead to a one percentage point reduction in output volatility. In the figure, the further toward the northeast corner in the panel, i.e., the higher level of ERS and IR a country pursues, the more negative the impact on output volatility. Below the threshold, however, it is true that the further toward the southeast corner, i.e., the higher level of ERS and the lower level of IR a country pursues, the more positive impact the impact on output volatility. In each of the panels, the scatter diagrams of ERS and IR are superimposed. The black circles indicate ERS and IR for the period of 2002-06 and the red "x's” for the 1992-96 period.

Insert Figure 4

\footnotetext{
${ }^{32}$ See for example Roubini (2008).

${ }^{33}$ In Model (8) in Table 1, $\hat{\alpha}_{1} T L M_{i t}+\hat{\alpha}_{3}\left(T L M_{i t} \times I R_{i t}\right)$ for ERS is found to be $0.017 E R S_{i t}-0.081\left(E R S_{i t} \times I R_{i t}\right)$. If the marginal effect is $-1 \%$, it must be that $-0.01=0.017 E R S_{i t}-0.081\left(E R S_{i t} \times I R_{i t}\right)$. If we solve this for $I R$, then we obtain $I R_{i t}=[0.017 / 0.081]-\left[-0.01 * 0.081 E R S_{i t}\right]$. We repeat this calculation for the $-2 \%$ impact, $-3 \%$ impact, etc. so as to create the other contours. The threshold of $21 \%$ of GDP can be obtained by solving $0=0.017 E R S_{i t}-0.081\left(E R S_{i t} \times I R_{i t}\right)$, implying $I R_{i t}=0.017 / 0.081=0.21$.
} 
The estimated coefficient on IR (level) is significantly positive in Columns (8) and (12) of Table 1, which indicates that, while a higher level of IR holding can lessen the positive effect of ERS, a higher level of IR holding itself is volatility-enhancing. Hence, it is essentially a tradeoff between holding more IR and pursuing greater exchange rate stability once the level of IR surpasses the threshold level. Our analysis here with Figure 4 focuses on the marginal effect of ERS and how it changes depending on the level of IR while keeping in mind that higher levels of IR are volatility-increasing.

These diagrams highlight several interesting observations. First, between the 1992-96 and 2002-06 periods, a period which encompasses the last wave of global crises, i.e., the Asian crisis of 1997-98, the Russian crisis of 1998, and the Argentina crisis of 2001-02, many countries, especially those in East Asia and Eastern Europe, increased their IR holding above the threshold. Second, the movement is not necessarily toward the northeast direction. Rather, it is around the threshold level where the effect of ERS is neutral (i.e., zero percentage point impact), unless they move much higher toward output volatility-reducing territory (such as China and Bulgaria). Third, while we observe a moderately positive association between ERS and IR, none of these observations are applicable to Latin American countries. Lastly, there are few countries that have achieved combinations of ERS and IR that reduce output volatility significantly. Countries such as Botswana, China, Hong Kong, Malaysia, Jordan, and Singapore are more of exceptions than the rule. However, at the very least, these estimates can explain why many countries, especially those with the intention of pursuing greater exchange rate stability, are motivated to hold very large international reserves.

\subsection{Is the Trilemma Still Binding?}

In the previous subsection, we have seen that some, but not many, developing countries have pursued higher levels of ERS and IR concurrently. Figure 4 illustrates that countries have continued to increase their IR holding, but are not necessarily moving toward the northeast corner where IR holdings allow greater ERS to have on net an output stabilizing impact. This trend still can be observed when the data are updated for 2007 (not reported). Why then, do these countries continue to increase their IR holding?

One possibility is that holding massive amounts of foreign reserves allows a relaxation of the trilemma, i.e., simultaneous achievement of all three trilemma goals. Figure 5 displays a scatter diagram for EMG countries’ ERS and MI_KAO (composite index of MI and KAOPEN), which the concept of the trilemma predicts should be negatively correlated. There are two groups of country-years shown in the diagram; the first group consists of country-years with IR holding greater than 21\% of GDP, the threshold above which ERS can have an output volatility-reducing effect (shown in Figure 4), while the second group consists of those with a IR holding less than 
$21 \%$ of GDP. If our previous conjecture is right, the (green) triangles - country-years with $>21 \%$ IR - in the diagram should be scattered above the circles - country-years with $<21 \%$ IR.

Insert Figure 5

Theoretically, these two variables should be negatively correlated - the higher the level of ERS a country pursues, the lower the level of MI-KAO, a proxy for the weighted average of $\mathrm{MI}$ and KAO chosen. In the figure, however, the fitted lines for both groups are barely negatively sloped, and the estimated coefficients are not statistically significant. We test whether the slopes and intercepts of these two fitted lines are statistically different. If the conjecture that higher levels of IR holding could relax the trilemma, a country should be able to pursue higher levels of MI-KAO with the same level of ERS, which would either make the slope flatter or raise the intercept, i.e., the conditional mean of MI-KAO. Simple coefficient equality tests reveal that the slopes of the two fitted lines are not statistically different from each other, but that the intercept for the fitted line for country-years with IR greater than $21 \%$ is significantly higher than that for the $<21 \%$ IR group. This is in line with the conjecture that higher levels of IR holding can allow a country to pursue a higher weighted average of MI and KAOPEN, i.e., relax the trilemma.

Given the findings from the output volatility regressions in Table 1, greater monetary independence in EMG countries might result in less output volatility. If a country holds level of IR higher than $21 \%$ of its GDP, it might be able to relax the trilemma, so that it might pursue greater monetary independence and financial openness while maintaining exchange rate stability. One obvious candidate for this interpretation is China. Figure 6 shows the trilemma configurations and IR holding for emerging market countries in East Asia and China. We observe that without giving up its exchange rate stability and monetary independence, China has increased its IR holding while allowing slowly increasing financial openness. This evidence is consistent with the view that countries' efforts to "relax the trilemma” can involve an increase in IR holding. This opportunity might have contributed to the global expansion of liquidity prior to the financial crisis of 2008-09. We leave formal testing this argument as part of our future research agenda. Insert Figure 6

\subsection{Is the Incidence of Current Crisis Consistent with Our Models?}

It is clear that the ongoing crisis is not just a phenomenon of the industrial countries, but one of global proportions. Given that we can identify the countries that are experiencing more severe economic conditions than others, we examine whether the current crisis situation is consistent with the findings reported above. Specifically, we use the data from 2007 and examine whether the values of the variables we have studied were, on the eve of the crisis, such that they 
signaled an incipient crisis. Table 6 presents the variables of interest for a group of emerging market countries: PCGDP, IR (both as \% of GDP), the three trilemma indexes, and the external finance variables. $d X$ refers to the change of the variable $X$ compared to the 2002-06 period. ${ }^{34}$ We also report swap lines provided by the U.S. Federal Reserve and rescue loans provided by the IMF (as of March 2009) in order to identify which countries experienced more severe economic conditions than others.

Insert Table 6

It is noteworthy that the size of swap lines or IMF rescue packages were not very large for most countries. For example, it was 2 - 3\% of GDP for Brazil, Mexico, and Korea, and was and $7 \%$ for Pakistan. It is only for Singapore and Hungary that the size of the additionally available IR is relatively substantial, around 18\% of GDP. Based on what we found in Figure 4, we can see that, except for Singapore and Hungary, the effect of these swap lines or IMF rescue loans in reducing output volatility is minimal. Obstfeld et al. (2009) also mention the limited amount of additional IR provided to developing countries, especially compared to industrialized countries, and argue that these additional reserves acted primarily as signals of impending crisis, in contrast to the case for industrial countries where additional reserves can have real effects by relaxing liquidity constraints. ${ }^{35}$ Our results are consistent with their observation.

Turning to the conditions pertaining to trilemma configurations and both internal and external financing, we find that among the countries with swap or rescue loan arrangements, Hungary, Korea, and Pakistan experienced a relatively rapid increase in net inflows of bank lending ('Other'). In Table 5, we see that countries with positive net inflows of 'other' investment tend to experience higher output volatility. Among the three countries, Hungary appears to have pursued the combination of MI and KAOPEN whereas Pakistan, that of MI and ERS. Both combinations, MI-KAO and MI-ERS, are found to result in bank lending flows having a bigger impact on output volatility (Table 5). Pakistan is also subject to higher output volatility because its level of financial development is not high, although it pursues greater exchange rate stability. Interestingly, several other East European countries, such as Lithuania, Poland, the Slovak Republic, and Russia also experienced large increases in net inflows of bank lending, which suggests that these economies should be subject to higher output volatility. ${ }^{36}$ In Table 5, we also found that higher levels of net inflows of portfolio investment increased output

\footnotetext{
${ }^{34}$ PCGDP is as of 2006 (or 2005 if the figure for 2006 is unavailable) because it is unavailable for 2007.

${ }^{35}$ They also argue that the fact that a more substantial amount of rescue reserves can be readily available for industrialized countries should be the reason why industrialized countries do not (have to) hold a massive amount of IR.

${ }^{36}$ Latvia, though not included in our sample, also experienced an influx of bank lending in this year and is experiencing a severe economic crisis in 2008-09.
} 
volatility. The effect is amplified when a country pursues a policy combination of ERS and KAO. Both Brazil and Argentina experienced a rapid increase in net inflow of portfolio investment, although neither pursued the policy combination of ERS and KAO. The table also shows that Venezuela might be exposed to higher output volatility; it pursued a fixed exchange rate although its international reserves/GDP ratio fell significantly while portfolio inflow increased. Casual observation thus confirms that the inferences obtained from our empirical analyses are consistent with the observations regarding the severity of the crisis in a number of countries.

\section{Concluding Remarks}

The global economy is currently experiencing the most severe recession since the Great Depression. While the United States was the epicenter of the crisis, the crisis has now spread to both industrial and developing countries. On the basis of past experience, we predict this crisis will spur a comprehensive reevaluation of international macroeconomic policies and the international financial architecture. Nonetheless, when policy makers decide on the specifics of international macroeconomic policies, they will have to confront the constraints on choices posed by the trilemma, as outlined in our previous paper (Aizenman, et al. 2008).

When it comes to deciding on the specifics of the combination of the three policies, the most crucial question is what kind of macroeconomic goals they would seek to achieve by choosing a combination of any two out of the three. In this paper, we tested how each the three policy choices as well as combination of any two could affect economic outcomes, such as output volatility, inflation volatility, and medium-term inflation rates, with a particular focus on developing countries.

We found countries with higher levels of monetary independence tend to experience lower output volatility. When we restrict our sample to emerging market economies, we also found that countries with higher levels of exchange rate fixity tend to experience higher output volatility. However, this effect can be mitigated by holding international reserves if the level of international reserves is higher than $21-24 \%$ of GDP. This result is consistent with the phenomenon of many emerging market countries accumulating massive international reserves.

We also found that countries with greater monetary autonomy tend to experience higher inflation, which may reflect countries' motives to monetize their debt. Countries with higher exchange rate stability are also found to experience lower inflation, a finding consistent with the literature. Furthermore, financial openness helps a country to achieve lower inflation, possibly indicating that globalization disciplines macroeconomic policy more than monetary autonomy.

Furthermore, we extended our regression analysis to investigate the following two questions relevant to the current crisis: (1) can financial development affect the link between 
trilemma policy configurations and output volatility?, and (2) how can external financing affect macroeconomic performances interactively with the trilemma configurations?

Regarding the effect of financial development on the link between the trilemma configurations and output volatility, we found a nonlinear effect among emerging market economies: medium-levels of financial development raise the volatility-enhancing impact of exchange rate stability. Greater financial liberalization reduces output volatility with highly developed financial markets, while it exacerbates output volatility with underdeveloped financial market, suggesting a synergistic effect between financial development and financial opening.

In regressions including variables measuring external financing, we found that net recipients of cross-border bank lending or portfolio flows - "hot money" - tend to experience higher output volatility. We also took a closer look at the effect of policy orientation on the effect of external financing and determined that the effect of different types of external financing depends upon the policy regime adopted by a country. First, net FDI inflows tend to dampen output volatility in general, but can raise volatility in a "financially closed" regime, i.e., one with greater monetary independence and more stable exchange rates. Net portfolio inflows can be volatility-increasing, with the effect greater for the countries with currency union or similar hardfix regimes. This type of regime, however, can dampen the volatility-enhancing effect of bank lending. Among the variables related to sovereignty debt, the greater is debt service, the more likely a country will experience higher levels of output volatility, especially when combined with greater exchange rate stability and financial openness. This result is entirely consistent with the “original sin” literature.

Our results potentially explain why many countries have been accumulating massive foreign exchange reserves. A motivation for countries to hold IR is the desire to relax the trilemma: massive IR holding allows countries to pursue both a higher level of exchange rate stability and a higher weighted average of the other two trilemma policies through active foreign exchange intervention. Given our finding that holding a higher level of IR than 21-24\% of GDP can dampen or even reverse the volatility-increasing effect of exchange rate stability, this conclusion is plausible.

Last, our empirical findings are consistent with the pattern of countries in macroeconomic distress; countries in turmoil do appear to be the ones with the trilemma variables and variables related to both internal and external financing at levels that contribute to higher output volatility. In other words, our model predicts higher output volatility for countries that in fact have experienced extreme economic distress. This outcome bolsters the validity of our empirical analysis. 
Acknowledgements: The financial support of faculty research funds of the UCSC and PSU is gratefully acknowledged. We would like to thank Eduardo Borensztein, Eduardo Cavallo, Camilo Tovar, Helen Popper, Reuven Glick, and the participants at the BIS-LACEA 2008 Rio meeting and the $3^{\text {rd }}$ JIMF-SCCIE conference for their useful comments and suggestions. 


\section{References}

Acemoglu, D., Johnson, S., Robinson, J., Thaicharoen, Y., 2003. Institutional Causes, Macroeconomic Symptoms: Volatility, Crises, and Growth, Journal of Monetary Economics, 50 (1), 49-123.

Aghion, P., Banerjee, A., Piketty, T., 1999. Dualism and Macroeconomic Volatility, Quarterly Journal of Economics, 114 (4),1359-97.

Aizenman, J., Chinn, M.D., Ito, H., 2008. Assessing the Emerging Global Financial Architecture: Measuring the Trilemma's Configurations over Time. NBER Working Paper Series, \#14533 (December).

Aizenman, J., Glick, R., 2009. Sterilization, Monetary Policy, and Global Financial Integration, Review of International Economics 17 (4), 816-840.

Alesina, A., Summers, L., 1993. Central Bank Independence and Macroeconomic Performance. Journal of Money, Credit and Banking 25 (2),151-162.

Bekaert, G., Harvey, C., Lundblad, C., 2001. Does Financial Liberalization Spur Growth? NBER Working Paper \#8245.

Bekaert, G., Harvey, C., Lundblad, C., 2000. Emerging Equity Market and Economic Development, NBER Working Paper No. 7763 (April).

Barro, R., Gordon, D, 1983. A Positive Theory of Monetary Policy in a Natural Rate Model, Journal of Political Economy, 91 (4), 589-610.

Blankenau,W., M.A. Kose, K. Yi, 2001, Can World Real Interest Rates Explain Business Cycles in a Small Open Economy? Journal of Economic Dynamics and Control, 25 (6), 867-89.

Calvo, G.A., Izquierdo, A., Mejía, L.F., 2004. On the Empirics of Sudden Stops: The Relevance of Balance-Sheet Effects. Research Department Working Paper 509. Washington, DC, United States: Inter-American Development Bank.

Cavallo, E.A., 2007. Output Volatility and Openness to Trade: A Reassessment Inter-American Development Bank Working Paper \#604 (April).

Cavallo, E.A, 2005. Trade, Gravity and Sudden Stops: On How Commercial Trade Openness Can Increase the Stability of Capital Flows. Cambridge, United States: Harvard University. Mimeographed document.

Caballero, R.J., Krishnamurthy, A., 2001, International and Domestic Collateral Constraints in a Model of Emerging Market Crises, Journal of Monetary Economics, 48 (3),513-48.

Cavallo, E.A., Frankel, J.A., 2004. Does Openness to Trade Make Countries More Vulnerable to Sudden Stops, or Less? NBER Working Paper 10957. Cambridge, United States: National Bureau of Economic Research. 
Cecchetti, S.G., Ehrmann, M., 1999. Does Inflation Targeting Increase Output Volatility? An International Comparison of Policymakers’ Preferences and Outcomes NBER Working Paper \#7426. Cambridge, MA : National Bureau of Economic Research (December).

Chinn, M. D., Ito, H., 2008. A New Measure of Financial Openness. Journal of Comparative Policy Analysis, 10, (3), 309 - 322.

Chinn, M. D., Ito, H., 2006. What Matters for Financial Development? Capital Controls, Institutions, and Interactions, Journal of Development Economics, 81 (1), 163-192.

Demirguc-Kent, A., Detragiache, E., 1998. Financial liberalization and financial fragility, Policy Research Working Paper Series 1917, Washington, D.C.: The World Bank.

Easterly, W., Islam, R., Stiglitz, J., 2001. Shaken and Stirred: Explaining Growth Volatility. In: B. Plesokovic and N. Stern, editors. Annual World Bank Conference on Development Economics. Washington, DC, United States: World Bank.

Edison, H. J., Klein, M. W. L. Ricci, Sløk, T., 2002. Capital Account Liberalization and Economic Performance: A Review of the Literature, IMF Working Paper (May).

Edison, H., J. Warnock, F. E., 2001. A simple measure of the intensity of capital controls, International Finance Discussion Paper \#708 (Washington, D.C.: Board of Governors of the Federal Reserve System, September).

Edwards, S., 2001. Capital Mobility and Economic Performance: Are Emerging Economies Different? NBER Working Paper No. 8076.

Edwards, S., 1999. How Effective are Capital Controls? Journal of Economic Perspectives 13 (4) : 65-84.

Eichengreen, B., Rose, A. K., Wyplosz, C., 1996. Contagious Currency Crises, NBER Working Paper 5681.

Glick, R., Hutchison, H. M., 2009. Navigating the Trilemma: Capital Flows and Monetary Policy in China, Journal of Asian Economics, 20(3): 205-224.

Glick, R., Hutchison, H. M., 2001. Banking and Currency Crises: How Common Are Twins? 3569, In R. Glick, Moreno, R., Spiegel, M., eds. Financial Crises in Emerging Markets. Cambridge, UK: Cambridge University Press.

Ghosh, A., Gulde A., Ostry, J., 1997. Does the Nominal Exchange Rate Regime Matter? NBER Working Paper No 5874.

Henry, P. B., 2000. Stock Market Liberalization, Economic Reform and Emerging Market Equity Prices, Journal of Finance 55 (2): 529-564.

Hnatkovska, V. and N. Loayza, 2005. Volatility and Growth in J. Aizenman, Pinto, B., eds. Managing Economic Volatility and Crises: A Practitioner’s Guide (Cambridge: Cambridge University Press, October). 
Haruka, D. S., 2007. Output Volatility and Large Output Drops in Emerging Market and Developing Countries, IMF Working Paper WP/07/114 (May). Washington, D.C.: International Monetary Fund.

Kaminsky, G., Reinhart, C., 1999. The Twin Crises: The Causes of Banking and Currency Balance-of-Payments Problems, American Economic Review 89, (3), 473-500.

King, R. G. and Levine, R., 1993. Finance and Growth: Schumpeter Might Be Right, Quarterly Journal of Economics, 108 (3), 717 - 738.

Kose, M. A., E. Prasad, K. Rogoff, Wei, S. J., 2006. Financial Globalization: A Reappraisal, IMF Working Paper, WP/06/189.

Kose, M.A., E. Prasad, Terrones, M., 2003. Financial Integration and Macroeconomic Volatility. IMF Working Paper WP/03/50. Washington, DC, United States: International Monetary Fund.

Krugman, P., 1993. Lessons of Massachusetts for EMU, The Transition to Economic and Monetary Union in Europe. In Giavazzi, F., Torres, F., (eds) (Cambridge: Cambridge University Press), 241-61.

Kydland, F. and Prescott, E., 1977. Rules Rather Than Discretion: The Inconsistency of Optimal Plans, Journal of Political Economy, 85 (3), 473-490.

Lane, P. R., Milesi-Ferretti, G. M., 2006. The External Wealth of Nations Mark II: Revised and Extended Estimates of Foreign Assets and Liabilities, 1970-2004. IMF Working Paper 06/69.

Loungani, P., A. Razin, Yuen, C., W. 2001. Capital Mobility and the Output-Inflation Tradeoff, Journal of Development Economics, 64, (1), 255-274.

Mishkin, F. S., Schmidt-Hebbel, K., 2007. Does Inflation Targeting Make a Difference? NBER Working Paper \#12876. Cambridge, MA : National Bureau of Economic Research.

Moreno R., Spiegel, M. M., 1997. Are Asian economies exempt from the "impossible trinity?": evidence from Singapore, Federal Reserve Bank of San Francisco, Pacific Basin Working Paper Series, 97-01.

Obstfeld, M., Shambaugh, J. C., Taylor, A. M., 2009. Financial Stability, Reserves, and Central Bank Swap Lines in the Panic of 2008. Paper prepared for the ASSA Meetings, San Francisco, January 3-5, 2009.

Obstfeld, M., Shambaugh, J. C., Taylor, A. M., 2005. The Trilemma in History: Tradeoffs among Exchange Rates, Monetary Policies, and Capital Mobility. Review of Economics and Statistics 87 (3), 423-38.

Prasad, E. S., 2008. Monetary Policy Independence, the Currency Regime, and the Capital Account in China. In Goldstein, M. and N. R. Lardy (Eds.), Debating China’s Exchange Rate Policy, Washington, D.C.: Peterson Institute for International Economics. 
Rajan, R.G., Zingales, L., 1998. Financial Dependence and Growth, American Economic Review 88 (3), 559 - 586.

Razin, A., Rose, K. A., 1994. Business-Cycle Volatility and Openness: an Exploratory CrossSectional Analysis, in Capital Mobility: The Impact on Consumption, Investment, and Growth. In L., Leiderman, and Razin A. (eds.), Cambridge: Cambridge University Press, 48-76.

Razin, A., Binyamini, A., 2007. Flattening the Short-Run Trade-Off Between Inflation and Domestic Activity: The Analytics of the Effects of Globalization. Kiel Working Paper No. 1363 (June). Kiel: Kiel Institute for World Economics.

Rodrik, D., 1998. Why Do More Open Economies Have Bigger Governments? Journal of Political Economy 106 (5), 997-1032.

Rogoff, K., 2003. Globalization and global disinflation. Federal Reserve Bank of Kansas City Economic Review, (4), 45-78.

Romer, D., 1993. Openness and Inflation: Theory and Evidence. Quarterly Journal of Economics 108, 869-903.

Roubini, N., 2008. Will the Bretton Woods (BW2) Regime Collapse Like the Original Bretton Woods Regime Did? The Coming End Game of BW2. mimeo. RGE Monitor (July 6).

Shambaugh, J. C., 2004. The Effects of Fixed Exchange Rates on Monetary Policy. Quarterly Journal of Economics 119 (1), 301-52.

Stultz, R., 1999. Globalization, Corporate Finance and the Cost of Capital, Journal of Applied Corporate Finance, 12 (3), 8-25.

Wurgler, J., 2000. Financial Markets and the Allocation of Capital, Journal of Financial Economics, 58 (1), 187 - 214. 
Table 1: Output Volatility, 1972 - 2006, Panels of 5-year Windows, Robust Regression

\begin{tabular}{|c|c|c|c|c|c|c|c|c|c|c|c|c|}
\hline & \multicolumn{6}{|c|}{ Less Developed Countries (LDC) } & \multicolumn{6}{|c|}{ Emerging Market Countries (EMG) } \\
\hline & $(1)$ & $(2)$ & $(3)$ & $(4)$ & $(5)$ & $(6)$ & $(7)$ & $(8)$ & $(9)$ & $(10)$ & $(11)$ & $(12)$ \\
\hline Relative Income & $\begin{array}{l}-0.032 \\
{[0.020]}\end{array}$ & $\begin{array}{c}-0.039 \\
{[0.020]^{*}}\end{array}$ & $\begin{array}{c}-0.034 \\
{[0.020]^{*}}\end{array}$ & $\begin{array}{c}-0.022 \\
{[0.020]}\end{array}$ & $\begin{array}{l}-0.031 \\
{[0.020]}\end{array}$ & $\begin{array}{c}-0.045 \\
{[0.021]^{* *}}\end{array}$ & $\begin{array}{c}-0.032 \\
{[0.024]}\end{array}$ & $\begin{array}{c}-0.04 \\
{[0.024]^{*}}\end{array}$ & $\begin{array}{c}-0.033 \\
{[0.024]}\end{array}$ & $\begin{array}{l}-0.026 \\
{[0.025]}\end{array}$ & $\begin{array}{c}-0.031 \\
{[0.024]}\end{array}$ & $\begin{array}{l}-0.039 \\
{[0.026]}\end{array}$ \\
\hline $\begin{array}{l}\text { Relative } \\
\text { Income, sq. }\end{array}$ & $\begin{array}{c}0.05 \\
{[0.024]^{* *}}\end{array}$ & $\begin{array}{c}0.062 \\
{[0.024]^{* *}}\end{array}$ & $\begin{array}{c}0.059 \\
{[0.024]^{* *}}\end{array}$ & $\begin{array}{c}0.034 \\
{[0.025]}\end{array}$ & $\begin{array}{c}0.057 \\
{[0.024]^{* *}}\end{array}$ & $\begin{array}{c}0.085 \\
{[0.026]^{* * *}}\end{array}$ & $\begin{array}{c}0.046 \\
{[0.030]}\end{array}$ & $\begin{array}{c}0.056 \\
{[0.030]^{*}}\end{array}$ & $\begin{array}{c}0.048 \\
{[0.029]^{*}}\end{array}$ & $\begin{array}{c}0.038 \\
{[0.032]}\end{array}$ & $\begin{array}{c}0.045 \\
{[0.029]}\end{array}$ & $\begin{array}{c}0.056 \\
{[0.034]}\end{array}$ \\
\hline $\begin{array}{l}\text { Change in US } \\
\text { real interest rate }\end{array}$ & $\begin{array}{c}0.173 \\
{[0.045]^{* * *}}\end{array}$ & $\begin{array}{c}0.171 \\
{[0.046]^{* * *}}\end{array}$ & $\begin{array}{c}0.166 \\
{[0.046]^{* * *}}\end{array}$ & $\begin{array}{c}0.166 \\
{[0.046]^{* * *}}\end{array}$ & $\begin{array}{c}0.168 \\
{[0.046]^{* * *}}\end{array}$ & $\begin{array}{c}0.17 \\
{[0.046]^{* * *}}\end{array}$ & $\begin{array}{c}0.204 \\
{[0.055]^{* * *}}\end{array}$ & $\begin{array}{c}0.212 \\
{[0.054]^{* * *}}\end{array}$ & $\begin{array}{c}0.2 \\
{[0.055]^{* * *}}\end{array}$ & $\begin{array}{c}0.198 \\
{[0.054]^{* * *}}\end{array}$ & $\begin{array}{c}0.196 \\
{[0.054]^{* * *}}\end{array}$ & $\begin{array}{c}0.2 \\
{[0.054]^{* * *}}\end{array}$ \\
\hline $\begin{array}{l}\text { Volatility of } \\
\text { TOT*OPN }\end{array}$ & $\begin{array}{c}0.037 \\
{[0.008]^{* * *}}\end{array}$ & $\begin{array}{c}0.037 \\
{[0.008]^{* * *}}\end{array}$ & $\begin{array}{c}0.036 \\
{[0.008]^{* * *}}\end{array}$ & $\begin{array}{c}0.036 \\
{[0.008]^{* * *}}\end{array}$ & $\begin{array}{c}0.035 \\
{[0.008]^{* * *}}\end{array}$ & $\begin{array}{c}0.035 \\
{[0.008]^{* * *}}\end{array}$ & $\begin{array}{c}0.006 \\
{[0.013]}\end{array}$ & $\begin{array}{c}0.003 \\
{[0.013]}\end{array}$ & $\begin{array}{c}0.011 \\
{[0.013]}\end{array}$ & $\begin{array}{c}0.013 \\
{[0.013]}\end{array}$ & $\begin{array}{c}0.006 \\
{[0.013]}\end{array}$ & $\begin{array}{c}0.001 \\
{[0.013]}\end{array}$ \\
\hline $\begin{array}{l}\text { Inflation } \\
\text { volatility }\end{array}$ & $\begin{array}{c}0.001 \\
{[0.001]}\end{array}$ & $\begin{array}{c}0.001 \\
{[0.001]}\end{array}$ & $\begin{array}{c}0.001 \\
{[0.001]}\end{array}$ & $\begin{array}{c}0.001 \\
{[0.001]}\end{array}$ & $\begin{array}{c}0.001 \\
{[0.001]}\end{array}$ & $\begin{array}{c}0.001 \\
{[0.001]}\end{array}$ & $\begin{array}{c}0.057 \\
{[0.005]^{* * *}}\end{array}$ & $\begin{array}{c}0.06 \\
{[0.005]^{* * *}}\end{array}$ & $\begin{array}{c}0.049 \\
{[0.005]^{* * *}}\end{array}$ & $\begin{array}{c}0.043 \\
{[0.005]^{* * *}}\end{array}$ & $\begin{array}{c}0.054 \\
{[0.005]^{* * *}}\end{array}$ & $\begin{array}{c}0.059 \\
{[0.005]^{* * *}}\end{array}$ \\
\hline $\begin{array}{l}\text { Fiscal } \\
\text { Procyclicality }\end{array}$ & $\begin{array}{c}0.003 \\
{[0.002]}\end{array}$ & $\begin{array}{c}0.003 \\
{[0.002]}\end{array}$ & $\begin{array}{c}0.003 \\
{[0.002]^{*}}\end{array}$ & $\begin{array}{c}0.003 \\
{[0.002]^{*}}\end{array}$ & $\begin{array}{c}0.003 \\
{[0.002]^{*}}\end{array}$ & $\begin{array}{c}0.003 \\
{[0.002]^{*}}\end{array}$ & $\begin{array}{c}0.005 \\
{[0.002]^{* *}}\end{array}$ & $\begin{array}{c}0.005 \\
{[0.002]^{* *}}\end{array}$ & $\begin{array}{c}0.004 \\
{[0.002]^{*}}\end{array}$ & $\begin{array}{c}0.005 \\
{[0.002]^{* *}}\end{array}$ & $\begin{array}{c}0.005 \\
{[0.002]^{* *}}\end{array}$ & $\begin{array}{c}0.005 \\
{[0.002]^{* *}}\end{array}$ \\
\hline Oil Exporters & $\begin{array}{c}0.011 \\
{[0.004]^{* * *}}\end{array}$ & $\begin{array}{c}0.012 \\
{[0.004]^{* * *}}\end{array}$ & $\begin{array}{c}0.011 \\
{[0.004]^{* * *}}\end{array}$ & $\begin{array}{c}0.011 \\
{[0.004]^{* * *}}\end{array}$ & $\begin{array}{c}0.011 \\
{[0.004]^{* * *}}\end{array}$ & $\begin{array}{c}0.011 \\
{[0.004]^{* * *}}\end{array}$ & $\begin{array}{c}0.011 \\
{[0.005]^{* *}}\end{array}$ & $\begin{array}{c}0.013 \\
{[0.005]^{* * *}}\end{array}$ & $\begin{array}{c}0.012 \\
{[0.005]^{* *}}\end{array}$ & $\begin{array}{c}0.012 \\
{[0.005]^{* * *}}\end{array}$ & $\begin{array}{c}0.01 \\
{[0.005]^{* *}}\end{array}$ & $\begin{array}{c}0.012 \\
{[0.005]^{* *}}\end{array}$ \\
\hline $\begin{array}{l}\text { Private credit } \\
\text { creation }\end{array}$ & $\begin{array}{c}-0.009 \\
{[0.005]^{*}}\end{array}$ & $\begin{array}{c}-0.009 \\
{[0.006]}\end{array}$ & $\begin{array}{c}-0.01 \\
{[0.005]^{*}}\end{array}$ & $\begin{array}{c}-0.009 \\
{[0.005]^{*}}\end{array}$ & $\begin{array}{c}-0.009 \\
{[0.005]^{*}}\end{array}$ & $\begin{array}{c}-0.009 \\
{[0.006]}\end{array}$ & $\begin{array}{c}-0.007 \\
{[0.006]}\end{array}$ & $\begin{array}{c}-0.004 \\
{[0.006]}\end{array}$ & $\begin{array}{c}-0.008 \\
{[0.006]}\end{array}$ & $\begin{array}{c}-0.008 \\
{[0.006]}\end{array}$ & $\begin{array}{c}-0.007 \\
{[0.006]}\end{array}$ & $\begin{array}{c}-0.003 \\
{[0.006]}\end{array}$ \\
\hline $\begin{array}{l}\text { Total } \\
\text { Reserve/GDP }\end{array}$ & $\begin{array}{c}0.018 \\
{[0.008]^{* *}} \\
\end{array}$ & $\begin{array}{c}0.049 \\
{[0.041]} \\
\end{array}$ & $\begin{array}{c}0.019 \\
{[0.008]^{* *}} \\
\end{array}$ & $\begin{array}{c}0.021 \\
{[0.033]}\end{array}$ & $\begin{array}{c}0.018 \\
{[0.009]^{* *}}\end{array}$ & $\begin{array}{c}0.045 \\
{[0.025]^{*}}\end{array}$ & $\begin{array}{c}0.026 \\
{[0.008]^{* * *}}\end{array}$ & $\begin{array}{c}0.105 \\
{[0.038]^{* * *}}\end{array}$ & $\begin{array}{c}0.028 \\
{[0.008]^{* * *}} \\
\end{array}$ & $\begin{array}{c}0.041 \\
{[0.035]} \\
\end{array}$ & $\begin{array}{c}0.028 \\
{[0.008]^{* * *}} \\
\end{array}$ & $\begin{array}{c}0.059 \\
{[0.024] * *} \\
\end{array}$ \\
\hline $\begin{array}{l}\text { Monetary } \\
\text { Independ. (MI) }\end{array}$ & $\begin{array}{c}-0.02 \\
{[0.008]^{* *}}\end{array}$ & $\begin{array}{c}-0.015 \\
{[0.012]}\end{array}$ & $\begin{array}{c}-0.019 \\
{[0.008]^{* *}}\end{array}$ & $\begin{array}{c}-0.016 \\
{[0.012]}\end{array}$ & & & $\begin{array}{c}-0.017 \\
{[0.010]^{*}}\end{array}$ & $\begin{array}{c}-0.005 \\
{[0.014]}\end{array}$ & $\begin{array}{c}-0.02 \\
{[0.010]^{* *}}\end{array}$ & $\begin{array}{c}-0.013 \\
{[0.013]}\end{array}$ & & \\
\hline MI x reserves & & $\begin{array}{c}-0.038 \\
{[0.067]}\end{array}$ & & $\begin{array}{l}-0.017 \\
{[0.063]}\end{array}$ & & & & $\begin{array}{l}-0.081 \\
{[0.063]}\end{array}$ & & $\begin{array}{c}-0.043 \\
{[0.061]}\end{array}$ & & \\
\hline $\begin{array}{l}\text { Exchange Rate } \\
\text { Stability (ERS) }\end{array}$ & $\begin{array}{l}-0.005 \\
{[0.004]}\end{array}$ & $\begin{array}{c}-0.001 \\
{[0.005]}\end{array}$ & & & $\begin{array}{c}-0.003 \\
{[0.004]}\end{array}$ & $\begin{array}{c}0.002 \\
{[0.005]}\end{array}$ & $\begin{array}{c}0.004 \\
{[0.005]}\end{array}$ & $\begin{array}{c}0.017 \\
{[0.007]^{* *}}\end{array}$ & & & $\begin{array}{c}0.005 \\
{[0.005]}\end{array}$ & $\begin{array}{c}0.017 \\
{[0.007]^{* *}}\end{array}$ \\
\hline ERS $\mathrm{x}$ reserves & & $\begin{array}{c}-0.029 \\
{[0.032]}\end{array}$ & & & & $\begin{array}{c}-0.034 \\
{[0.031]}\end{array}$ & & $\begin{array}{c}-0.081 \\
{[0.033]^{* *}}\end{array}$ & & & & $\begin{array}{c}-0.072 \\
{[0.032]^{* *}}\end{array}$ \\
\hline KA Openness & & & $\begin{array}{c}-0.005 \\
{[0.004]}\end{array}$ & $\begin{array}{l}-0.007 \\
{[0.005]}\end{array}$ & $\begin{array}{l}-0.004 \\
{[0.004]}\end{array}$ & $\begin{array}{l}-0.002 \\
{[0.005]}\end{array}$ & & & $\begin{array}{l}-0.004 \\
{[0.005]}\end{array}$ & $\begin{array}{l}-0.005 \\
{[0.006]}\end{array}$ & $\begin{array}{l}-0.001 \\
{[0.004]}\end{array}$ & $\begin{array}{l}-0.003 \\
{[0.006]}\end{array}$ \\
\hline $\begin{array}{l}K A O P E N \mathrm{x} \\
\text { reserves }\end{array}$ & & & & $\begin{array}{c}0.015 \\
{[0.025]}\end{array}$ & & $\begin{array}{c}-0.02 \\
{[0.025]}\end{array}$ & & & & $\begin{array}{c}0.011 \\
{[0.026]}\end{array}$ & & $\begin{array}{c}0.008 \\
{[0.026]}\end{array}$ \\
\hline \# of Obs. & 412 & 412 & 412 & 412 & 412 & 412 & 208 & 208 & 208 & 208 & 208 & 208 \\
\hline Adjusted R2 & 0.21 & 0.21 & 0.22 & 0.2 & 0.21 & 0.22 & 0.47 & 0.5 & 0.44 & 0.41 & 0.46 & 0.5 \\
\hline
\end{tabular}

Notes: Robust standard errors in brackets. * significant at $10 \%$; ${ }^{* *}$ significant at $5 \%$; ${ }^{* * *}$ significant at $1 \%$. The estimated coefficients of the dummies for East Asia and Pacific and Sub-Saharan Africa are not reported. 
Table 2: Inflation, 1972 - 2006, Panels of 5-year Windows, Robust Regression

\begin{tabular}{|c|c|c|c|c|c|c|c|c|c|c|c|c|}
\hline & \multicolumn{6}{|c|}{ Less Developed Countries (LDC) } & \multicolumn{6}{|c|}{ Emerging Market Countries (EMG) } \\
\hline & (1) & $(2)$ & $(3)$ & $(4)$ & (5) & (6) & (7) & $(8)$ & $(9)$ & $(10)$ & $(11)$ & (12) \\
\hline Relative Income & $\begin{array}{l}-0.028 \\
{[0.052]}\end{array}$ & $\begin{array}{l}-0.015 \\
{[0.052]}\end{array}$ & $\begin{array}{c}0.013 \\
{[0.053]}\end{array}$ & $\begin{array}{c}0.036 \\
{[0.055]}\end{array}$ & $\begin{array}{l}-0.028 \\
{[0.050]}\end{array}$ & $\begin{array}{c}0.005 \\
{[0.052]}\end{array}$ & $\begin{array}{l}-0.079 \\
{[0.090]}\end{array}$ & $\begin{array}{l}-0.062 \\
{[0.092]}\end{array}$ & $\begin{array}{l}-0.019 \\
{[0.085]}\end{array}$ & $\begin{array}{l}-0.039 \\
{[0.090]}\end{array}$ & $\begin{array}{l}-0.073 \\
{[0.088]}\end{array}$ & $\begin{array}{l}-0.071 \\
{[0.095]}\end{array}$ \\
\hline $\begin{array}{l}\text { Relative } \\
\text { Income, sq. }\end{array}$ & $\begin{array}{c}0.059 \\
{[0.062]}\end{array}$ & $\begin{array}{c}0.045 \\
{[0.063]}\end{array}$ & $\begin{array}{c}0.014 \\
{[0.065]}\end{array}$ & $\begin{array}{c}-0.022 \\
{[0.068]}\end{array}$ & $\begin{array}{c}0.074 \\
{[0.060]}\end{array}$ & $\begin{array}{c}0.027 \\
{[0.064]}\end{array}$ & $\begin{array}{c}0.122 \\
{[0.110]}\end{array}$ & $\begin{array}{c}0.101 \\
{[0.112]}\end{array}$ & $\begin{array}{c}0.075 \\
{[0.104]}\end{array}$ & $\begin{array}{c}0.107 \\
{[0.115]}\end{array}$ & $\begin{array}{c}0.134 \\
{[0.108]}\end{array}$ & $\begin{array}{c}0.138 \\
{[0.122]}\end{array}$ \\
\hline $\begin{array}{l}\text { World Output } \\
\text { Gap }\end{array}$ & $\begin{array}{c}0.876 \\
{[0.310] * * *}\end{array}$ & $\begin{array}{c}0.91 \\
{[0.310] * * *}\end{array}$ & $\begin{array}{c}0.71 \\
{[0.321]^{* *}}\end{array}$ & $\begin{array}{c}0.714 \\
{[0.321]^{* *}}\end{array}$ & $\begin{array}{c}0.897 \\
{[0.300]^{* * *}}\end{array}$ & $\begin{array}{c}0.921 \\
{[0.298] * * *}\end{array}$ & $\begin{array}{c}0.994 \\
{[0.440]^{* *}}\end{array}$ & $\begin{array}{c}1.016 \\
{[0.444]^{* *}}\end{array}$ & $\begin{array}{c}0.781 \\
{[0.422]^{*}}\end{array}$ & $\begin{array}{c}0.812 \\
{[0.425]^{*}}\end{array}$ & $\begin{array}{c}0.888 \\
{[0.433]^{* *}}\end{array}$ & $\begin{array}{c}0.939 \\
{[0.431]^{* *}}\end{array}$ \\
\hline Trade openness & $\begin{array}{c}-0.013 \\
{[0.008]^{*}}\end{array}$ & $\begin{array}{c}-0.014 \\
{[0.008]^{*}}\end{array}$ & $\begin{array}{c}-0.015 \\
{[0.008]^{*}}\end{array}$ & $\begin{array}{c}-0.018 \\
{[0.008]^{* *}}\end{array}$ & $\begin{array}{l}-0.008 \\
{[0.007]}\end{array}$ & $\begin{array}{l}-0.012 \\
{[0.008]}\end{array}$ & $\begin{array}{c}-0.012 \\
{[0.011]}\end{array}$ & $\begin{array}{l}-0.011 \\
{[0.011]}\end{array}$ & $\begin{array}{c}-0.004 \\
{[0.011]}\end{array}$ & $\begin{array}{l}-0.002 \\
{[0.012]}\end{array}$ & $\begin{array}{c}-0.004 \\
{[0.011]}\end{array}$ & $\begin{array}{c}-0.001 \\
{[0.012]}\end{array}$ \\
\hline $\begin{array}{l}\text { Volatility of } \\
\text { TOT*OPN }\end{array}$ & $\begin{array}{c}0.032 \\
{[0.021]}\end{array}$ & $\begin{array}{c}0.031 \\
{[0.021]}\end{array}$ & $\begin{array}{c}0.027 \\
{[0.022]}\end{array}$ & $\begin{array}{c}0.025 \\
{[0.022]}\end{array}$ & $\begin{array}{c}0.022 \\
{[0.020]}\end{array}$ & $\begin{array}{c}0.02 \\
{[0.020]}\end{array}$ & $\begin{array}{c}0.068 \\
{[0.040]^{*}}\end{array}$ & $\begin{array}{c}0.07 \\
{[0.041]^{*}}\end{array}$ & $\begin{array}{c}0.052 \\
{[0.039]}\end{array}$ & $\begin{array}{c}0.051 \\
{[0.039]}\end{array}$ & $\begin{array}{c}0.066 \\
{[0.040]^{*}}\end{array}$ & $\begin{array}{c}0.067 \\
{[0.039]^{*}}\end{array}$ \\
\hline $\begin{array}{l}\text { Inflation } \\
\text { volatility }\end{array}$ & $\begin{array}{c}0.311 \\
{[0.013]^{* * *}}\end{array}$ & $\begin{array}{c}0.31 \\
{[0.013]^{* * *}}\end{array}$ & $\begin{array}{c}0.295 \\
{[0.013]^{* * *}}\end{array}$ & $\begin{array}{c}0.293 \\
{[0.013]^{* * *}}\end{array}$ & $\begin{array}{c}0.304 \\
{[0.012]^{* * *}}\end{array}$ & $\begin{array}{c}0.303 \\
{[0.012]^{* * *}}\end{array}$ & $\begin{array}{c}0.443 \\
{[0.023]^{* * *}}\end{array}$ & $\begin{array}{c}0.444 \\
{[0.023]^{* * *}}\end{array}$ & $\begin{array}{c}0.443 \\
{[0.023]^{* * *}}\end{array}$ & $\begin{array}{c}0.446 \\
{[0.023]^{* * *}}\end{array}$ & $\begin{array}{c}0.423 \\
{[0.023]^{* * *}}\end{array}$ & $\begin{array}{c}0.432 \\
{[0.023]^{* * *}}\end{array}$ \\
\hline $\begin{array}{l}\text { Private Credit } \\
\text { Creation }\end{array}$ & $\begin{array}{l}-0.016 \\
{[0.013]}\end{array}$ & $\begin{array}{c}-0.022 \\
{[0.013]}\end{array}$ & $\begin{array}{c}-0.011 \\
{[0.014]}\end{array}$ & $\begin{array}{c}-0.014 \\
{[0.014]}\end{array}$ & $\begin{array}{l}-0.017 \\
{[0.013]}\end{array}$ & $\begin{array}{c}-0.025 \\
{[0.013]^{*}}\end{array}$ & $\begin{array}{c}-0.026 \\
{[0.018]}\end{array}$ & $\begin{array}{c}-0.031 \\
{[0.019]}\end{array}$ & $\begin{array}{c}-0.039 \\
{[0.018]^{* *}}\end{array}$ & $\begin{array}{c}-0.039 \\
{[0.018]^{* *}}\end{array}$ & $\begin{array}{c}-0.031 \\
{[0.018]^{*}}\end{array}$ & $\begin{array}{c}-0.037 \\
{[0.018]^{* *}}\end{array}$ \\
\hline $\begin{array}{l}\text { M2 Growth } \\
\text { Volatility }\end{array}$ & $\begin{array}{c}0.137 \\
{[0.036]^{* * *}}\end{array}$ & $\begin{array}{c}0.146 \\
{[0.036] * * *}\end{array}$ & $\begin{array}{c}0.116 \\
{[0.038]^{* * *}}\end{array}$ & $\begin{array}{c}0.116 \\
{[0.037]^{* * *}}\end{array}$ & $\begin{array}{c}0.144 \\
{[0.035]^{* * *}}\end{array}$ & $\begin{array}{c}0.149 \\
{[0.035]^{* * *}}\end{array}$ & $\begin{array}{c}0.128 \\
{[0.051]^{* *}}\end{array}$ & $\begin{array}{c}0.136 \\
{[0.052]^{* * *}}\end{array}$ & $\begin{array}{c}0.155 \\
{[0.050] * * *}\end{array}$ & $\begin{array}{c}0.145 \\
{[0.050]^{* * *}}\end{array}$ & $\begin{array}{c}0.178 \\
{[0.051]^{* * *}}\end{array}$ & $\begin{array}{c}0.169 \\
{[0.050]^{* * *}}\end{array}$ \\
\hline $\begin{array}{l}\text { Fiscal } \\
\text { Procyclicality }\end{array}$ & $\begin{array}{l}-0.001 \\
{[0.005]}\end{array}$ & $\begin{array}{c}-0.001 \\
{[0.005]}\end{array}$ & $\begin{array}{c}0.003 \\
{[0.005]}\end{array}$ & $\begin{array}{c}0.003 \\
{[0.005]}\end{array}$ & $\begin{array}{c}-0.003 \\
{[0.005]}\end{array}$ & $\begin{array}{c}-0.002 \\
{[0.005]}\end{array}$ & $\begin{array}{c}-0.01 \\
{[0.007]}\end{array}$ & $\begin{array}{c}-0.01 \\
{[0.007]}\end{array}$ & $\begin{array}{l}-0.008 \\
{[0.007]}\end{array}$ & $\begin{array}{l}-0.008 \\
{[0.007]}\end{array}$ & $\begin{array}{c}-0.013 \\
{[0.007]^{*}}\end{array}$ & $\begin{array}{c}-0.012 \\
{[0.007]^{*}}\end{array}$ \\
\hline Oil Shock & $\begin{array}{c}0.044 \\
{[0.005]^{* * *}}\end{array}$ & $\begin{array}{c}0.044 \\
{[0.006]^{* * *}}\end{array}$ & $\begin{array}{c}0.038 \\
{[0.006]^{* * *}}\end{array}$ & $\begin{array}{c}0.037 \\
{[0.006]^{* * *}}\end{array}$ & $\begin{array}{c}0.04 \\
{[0.005]^{* * *}}\end{array}$ & $\begin{array}{c}0.04 \\
{[0.005]^{* * *}}\end{array}$ & $\begin{array}{c}0.027 \\
{[0.008]^{* * *}}\end{array}$ & $\begin{array}{c}0.026 \\
{[0.008]^{* * *}}\end{array}$ & $\begin{array}{c}0.015 \\
{[0.008]^{*}}\end{array}$ & $\begin{array}{c}0.015 \\
{[0.008]^{*}}\end{array}$ & $\begin{array}{c}0.02 \\
{[0.008]^{* *}}\end{array}$ & $\begin{array}{c}0.02 \\
{[0.008]^{* *}}\end{array}$ \\
\hline $\begin{array}{l}\text { Total } \\
\text { Reserve/GDP }\end{array}$ & $\begin{array}{l}-0.021 \\
{[0.024]} \\
\end{array}$ & $\begin{array}{l}-0.122 \\
{[0.104]} \\
\end{array}$ & $\begin{array}{c}0.014 \\
{[0.025]} \\
\end{array}$ & $\begin{array}{l}-0.002 \\
{[0.089]} \\
\end{array}$ & $\begin{array}{c}-0.01 \\
{[0.024]} \\
\end{array}$ & $\begin{array}{c}-0.136 \\
{[0.061]^{* *}} \\
\end{array}$ & $\begin{array}{l}-0.023 \\
{[0.030]} \\
\end{array}$ & $\begin{array}{c}-0.138 \\
{[0.121]} \\
\end{array}$ & $\begin{array}{l}-0.018 \\
{[0.029]}\end{array}$ & $\begin{array}{c}0.01 \\
{[0.108]}\end{array}$ & $\begin{array}{c}-0.02 \\
{[0.030]} \\
\end{array}$ & $\begin{array}{c}-0.048 \\
{[0.076]} \\
\end{array}$ \\
\hline $\begin{array}{l}\text { Monetary } \\
\text { Independ. (MI) }\end{array}$ & $\begin{array}{c}0.037 \\
{[0.022]^{*}}\end{array}$ & $\begin{array}{c}0.033 \\
{[0.030]}\end{array}$ & $\begin{array}{c}0.063 \\
{[0.022]^{* * *}}\end{array}$ & $\begin{array}{c}0.067 \\
{[0.031]^{* *}}\end{array}$ & & & $\begin{array}{c}0.034 \\
{[0.031]}\end{array}$ & $\begin{array}{c}0.012 \\
{[0.043]}\end{array}$ & $\begin{array}{c}0.02 \\
{[0.031]}\end{array}$ & $\begin{array}{c}0.019 \\
{[0.042]}\end{array}$ & & \\
\hline MI x reserves & & $\begin{array}{c}0.029 \\
{[0.169]}\end{array}$ & & $\begin{array}{l}-0.067 \\
{[0.166]}\end{array}$ & & & & $\begin{array}{c}0.115 \\
{[0.197]}\end{array}$ & & $\begin{array}{c}0.002 \\
{[0.188]}\end{array}$ & & \\
\hline $\begin{array}{l}\text { Exchange Rate } \\
\text { Stability (ERS) }\end{array}$ & $\begin{array}{c}-0.074 \\
{[0.010]^{* * *}}\end{array}$ & $\begin{array}{c}-0.096 \\
{[0.014]^{* * *}}\end{array}$ & & & $\begin{array}{c}-0.08 \\
{[0.009]^{* * *}}\end{array}$ & $\begin{array}{c}-0.099 \\
{[0.013]^{* * *}}\end{array}$ & $\begin{array}{c}-0.04 \\
{[0.016]^{* *}}\end{array}$ & $\begin{array}{c}-0.059 \\
{[0.023]^{* * *}}\end{array}$ & & & $\begin{array}{c}-0.042 \\
{[0.016]^{* * *}}\end{array}$ & $\begin{array}{c}-0.059 \\
{[0.021]^{* * *}}\end{array}$ \\
\hline ERS $\mathrm{x}$ reserves & & $\begin{array}{c}0.161 \\
{[0.082]^{*}}\end{array}$ & & & & $\begin{array}{c}0.152 \\
{[0.075]^{* *}}\end{array}$ & & $\begin{array}{c}0.118 \\
{[0.102]}\end{array}$ & & & & $\begin{array}{c}0.112 \\
{[0.097]}\end{array}$ \\
\hline KA Openness & & & $\begin{array}{c}-0.037 \\
{[0.011]^{* * *}}\end{array}$ & $\begin{array}{c}-0.051 \\
{[0.015]^{* * *}}\end{array}$ & $\begin{array}{c}-0.048 \\
{[0.010]^{* * *}}\end{array}$ & $\begin{array}{c}-0.059 \\
{[0.013]^{* * *}}\end{array}$ & & & $\begin{array}{c}-0.048 \\
{[0.014]^{* * *}}\end{array}$ & $\begin{array}{c}-0.038 \\
{[0.019]^{* *}}\end{array}$ & $\begin{array}{c}-0.052 \\
{[0.014]^{* * *}}\end{array}$ & $\begin{array}{c}-0.042 \\
{[0.018]^{* *}}\end{array}$ \\
\hline $\begin{array}{l}\text { KAOPEN x } \\
\text { reserves }\end{array}$ & & & & $\begin{array}{c}0.095 \\
{[0.068]} \\
\end{array}$ & & $\begin{array}{c}0.086 \\
{[0.064]} \\
\end{array}$ & & & & $\begin{array}{c}-0.057 \\
{[0.086]}\end{array}$ & & $\begin{array}{c}-0.058 \\
{[0.086]}\end{array}$ \\
\hline \# of Obs. & 403 & 403 & 403 & 403 & 403 & 403 & 203 & 203 & 203 & 203 & 203 & 203 \\
\hline Adjusted R2 & 0.72 & 0.72 & 0.68 & 0.68 & 0.73 & 0.74 & 0.78 & 0.78 & 0.8 & 0.8 & 0.79 & 0.8 \\
\hline
\end{tabular}

Notes: Robust standard errors in brackets. * significant at $10 \%$; ** significant at $5 \%$; ** significant at $1 \%$. The estimated coefficients of the dummies for Latin American and the Caribbean and Eastern Europe are not reported. 
Table 3: Output Volatility: the Trilemma Indexes Interacted w/ different levels of PCGDP

\begin{tabular}{|c|c|c|c|c|c|c|}
\hline & \multicolumn{3}{|c|}{ Developing Countries (LDC) } & \multicolumn{3}{|c|}{ Emerging Market Countries (EMG) } \\
\hline & $(1)$ & $(2)$ & $(3)$ & (4) & (5) & $(6)$ \\
\hline $\begin{array}{l}\text { Private credit creation } \\
\text { (\% of GDP) }\end{array}$ & $\begin{array}{r}-0.012 \\
{[0.008]} \\
\end{array}$ & $\begin{array}{c}-0.013 \\
{[0.007]^{*}}\end{array}$ & $\begin{array}{c}-0.011 \\
{[0.008]}\end{array}$ & $\begin{array}{c}0.001 \\
{[0.008]} \\
\end{array}$ & $\begin{array}{c}0.001 \\
{[0.007]} \\
\end{array}$ & $\begin{array}{l}-0.005 \\
{[0.008]} \\
\end{array}$ \\
\hline $\begin{array}{l}\text { MI x } \\
\text { Int'l reserves }\end{array}$ & $\begin{array}{r}-0.042 \\
{[0.068]}\end{array}$ & & $\begin{array}{c}-0.023 \\
{[0.065]}\end{array}$ & $\begin{array}{l}-0.092 \\
{[0.068]}\end{array}$ & & $\begin{array}{c}-0.068 \\
{[0.065]}\end{array}$ \\
\hline $\begin{array}{l}\text { MI x } \\
\text { High PCGDP }\end{array}$ & $\begin{array}{l}-0.014 \\
{[0.017]}\end{array}$ & & $\begin{array}{l}-0.009 \\
{[0.016]}\end{array}$ & $\begin{array}{l}-0.006 \\
{[0.020]}\end{array}$ & & $\begin{array}{c}-0.01 \\
{[0.017]}\end{array}$ \\
\hline $\begin{array}{l}\text { MI x } \\
\quad \text { Medium PCGDP }\end{array}$ & $\begin{array}{l}-0.016 \\
{[0.012]}\end{array}$ & & $\begin{array}{l}-0.019 \\
{[0.012]}\end{array}$ & $\begin{array}{l}-0.007 \\
{[0.014]}\end{array}$ & & $\begin{array}{l}-0.016 \\
{[0.014]}\end{array}$ \\
\hline $\begin{array}{l}\text { MI x } \\
\text { Low PCGDP }\end{array}$ & $\begin{array}{l}-0.005 \\
{[0.015]}\end{array}$ & & $\begin{array}{l}-0.018 \\
{[0.013]}\end{array}$ & $\begin{array}{r}0.009 \\
{[0.023]} \\
\end{array}$ & & $\begin{array}{l}-0.022 \\
{[0.018]}\end{array}$ \\
\hline $\begin{array}{l}\text { ERS x } \\
\text { Int'l reserves }\end{array}$ & $\begin{array}{l}-0.036 \\
{[0.033]} \\
\end{array}$ & $\begin{array}{c}-0.042 \\
{[0.031]} \\
\end{array}$ & & $\begin{array}{c}-0.082 \\
{[0.037]^{* *}}\end{array}$ & $\begin{array}{c}-0.067 \\
{[0.032]^{* *}}\end{array}$ & \\
\hline $\begin{array}{l}\text { ERS x } \\
\text { High PCGDP }\end{array}$ & $\begin{array}{c}0.002 \\
{[0.010]}\end{array}$ & $\begin{array}{c}0.012 \\
{[0.009]}\end{array}$ & & $\begin{array}{c}0.013 \\
{[0.012]}\end{array}$ & $\begin{array}{c}0.017 \\
{[0.009]^{*}}\end{array}$ & \\
\hline $\begin{array}{l}\text { ERS x } \\
\quad \text { Medium PCGDP }\end{array}$ & $\begin{array}{c}0.003 \\
{[0.006]}\end{array}$ & $\begin{array}{c}0.003 \\
{[0.005]}\end{array}$ & & $\begin{array}{c}0.018 \\
{[0.007]^{* *}}\end{array}$ & $\begin{array}{c}0.017 \\
{[0.007]^{* *}}\end{array}$ & \\
\hline $\begin{array}{l}\text { ERS x } \\
\text { Low PCGDP }\end{array}$ & $\begin{array}{l}-0.011 \\
{[0.007]} \\
\end{array}$ & $\begin{array}{l}-0.005 \\
{[0.006]} \\
\end{array}$ & & $\begin{array}{c}0.019 \\
{[0.016]} \\
\end{array}$ & $\begin{array}{c}0.005 \\
{[0.010]} \\
\end{array}$ & \\
\hline $\begin{array}{l}\text { KAOPEN x } \\
\text { Int'l reserves }\end{array}$ & & $\begin{array}{c}-0.014 \\
{[0.027]}\end{array}$ & $\begin{array}{l}-0.001 \\
{[0.027]}\end{array}$ & & $\begin{array}{c}0.026 \\
{[0.027]}\end{array}$ & $\begin{array}{c}0.032 \\
{[0.027]}\end{array}$ \\
\hline $\begin{array}{l}\text { KAOPEN x } \\
\text { High PCGDP }\end{array}$ & & $\begin{array}{l}-0.012 \\
{[0.010]}\end{array}$ & $\begin{array}{l}-0.015 \\
{[0.009]}\end{array}$ & & $\begin{array}{c}-0.012 \\
{[0.010]}\end{array}$ & $\begin{array}{c}-0.018 \\
{[0.010]^{*}}\end{array}$ \\
\hline $\begin{array}{l}\text { KAOPEN x } \\
\text { Medium PCGDP }\end{array}$ & & $\begin{array}{c}0 \\
{[0.006]}\end{array}$ & $\begin{array}{c}0 \\
{[0.006]}\end{array}$ & & $\begin{array}{l}-0.005 \\
{[0.006]}\end{array}$ & $\begin{array}{c}-0.008 \\
{[0.006]}\end{array}$ \\
\hline $\begin{array}{l}\text { KAOPEN } \mathrm{x} \\
\text { LOW PCGDP }\end{array}$ & & $\begin{array}{r}-0.004 \\
{[0.009]} \\
\end{array}$ & $\begin{array}{c}-0.01 \\
{[0.010]}\end{array}$ & & $\begin{array}{c}0.037 \\
{[0.016]^{* *}} \\
\end{array}$ & $\begin{array}{c}0.039 \\
{[0.018]^{* *}} \\
\end{array}$ \\
\hline Adjusted R2 & 0.23 & 0.24 & 0.23 & 0.49 & 0.48 & 0.44 \\
\hline \multicolumn{7}{|c|}{$\begin{array}{l}\text { Significance of the estimated coefficients of the interaction terms } b / w \text { the trilemma indexes and different PCGDP groups } \\
\text { is tested using a Wald test. }\end{array}$} \\
\hline MI: High vs. Med. & 0.04 & & 0.85 & 0.00 & & 0.26 \\
\hline MI: Med. vs. Low & 1.25 & & 0.03 & 0.60 & & 0.24 \\
\hline MI: High vs. Low & 0.32 & & 0.42 & 0.42 & & 0.51 \\
\hline ERS: High vs. Med. & 0.02 & 1.30 & & 0.17 & 0.00 & \\
\hline ERS: Med. vs. Low & $4.39 * *$ & $2.60 *$ & & 0.01 & 1.57 & \\
\hline ERS: High vs. Low & 1.82 & $3.70 * *$ & & 0.11 & 1.05 & \\
\hline KAO: High vs. Med. & & 1.81 & $2.74 *$ & & 0.45 & 1.27 \\
\hline KAO: Med. vs. Low & & 0.19 & 0.81 & & $6.61^{* * *}$ & $6.83 * * *$ \\
\hline KAO: High vs. Low & & 0.52 & 0.17 & & $7.35 * * *$ & $8.84 * * *$ \\
\hline
\end{tabular}

Note: The estimation models include the benchmark macroeconomic variables and other characteristic dummies though their estimation results are omitted to conserve space. 
Table 4: The Impact of External Financing: Less Developed Countries

\begin{tabular}{|c|c|c|c|c|c|c|}
\hline \multirow[t]{2}{*}{ Dependent Variable: } & \multicolumn{3}{|c|}{ Output Volatility } & \multicolumn{3}{|c|}{ Level of Inflation } \\
\hline & $(1)$ & $(2)$ & (3) & $(7)$ & $(8)$ & $(9)$ \\
\hline Total Reserve/GDP & $\begin{array}{c}0.055 \\
{[0.057]}\end{array}$ & $\begin{array}{l}-0.021 \\
{[0.054]}\end{array}$ & $\begin{array}{c}0.037 \\
{[0.036]}\end{array}$ & $\begin{array}{c}-0.089 \\
{[0.142]}\end{array}$ & $\begin{array}{c}0.162 \\
{[0.142]}\end{array}$ & $\begin{array}{l}-0.114 \\
{[0.087]}\end{array}$ \\
\hline Currency Crisis & $\begin{array}{c}0.006 \\
{[0.003]^{* *}}\end{array}$ & $\begin{array}{c}0.006 \\
{[0.003]^{*}}\end{array}$ & $\begin{array}{c}0.005 \\
{[0.003]^{*}}\end{array}$ & $\begin{array}{c}0.041 \\
{[0.007]^{* * *}}\end{array}$ & $\begin{array}{c}0.043 \\
{[0.008]^{* * *}}\end{array}$ & $\begin{array}{c}0.037 \\
{[0.007]^{* * *}}\end{array}$ \\
\hline Net FDI inflows/GDP & $\begin{array}{c}-0.021 \\
{[0.074]}\end{array}$ & $\begin{array}{c}0.008 \\
{[0.075]}\end{array}$ & $\begin{array}{c}0.001 \\
{[0.075]}\end{array}$ & $\begin{array}{c}-0.377 \\
{[0.203]^{*}}\end{array}$ & $\begin{array}{c}-0.293 \\
{[0.215]}\end{array}$ & $\begin{array}{c}-0.297 \\
{[0.200]}\end{array}$ \\
\hline Net portfolio inflows/GDP & $\begin{array}{c}0.127 \\
{[0.087]}\end{array}$ & $\begin{array}{c}0.141 \\
{[0.087]^{*}}\end{array}$ & $\begin{array}{c}0.154 \\
{[0.087]^{*}}\end{array}$ & $\begin{array}{l}-0.087 \\
{[0.300]}\end{array}$ & $\begin{array}{l}-0.083 \\
{[0.320]}\end{array}$ & $\begin{array}{l}-0.104 \\
{[0.299]}\end{array}$ \\
\hline Net 'other' inflows/GDP & $\begin{array}{c}0.047 \\
{[0.030]}\end{array}$ & $\begin{array}{c}0.053 \\
{[0.030]^{*}}\end{array}$ & $\begin{array}{c}0.058 \\
{[0.030]^{*}}\end{array}$ & $\begin{array}{c}-0.005 \\
{[0.070]}\end{array}$ & $\begin{array}{c}0.075 \\
{[0.073]}\end{array}$ & $\begin{array}{c}0.045 \\
{[0.068]}\end{array}$ \\
\hline $\begin{array}{l}\text { Short-term Debt } \\
\text { (as \% of total external debt) }\end{array}$ & $\begin{array}{c}-0.003 \\
{[0.017]}\end{array}$ & $\begin{array}{c}0.005 \\
{[0.017]}\end{array}$ & $\begin{array}{c}0.006 \\
{[0.017]}\end{array}$ & $\begin{array}{c}0.057 \\
{[0.042]}\end{array}$ & $\begin{array}{c}0.094 \\
{[0.044]^{* *}}\end{array}$ & $\begin{array}{c}0.085 \\
{[0.041]^{* *}}\end{array}$ \\
\hline $\begin{array}{l}\text { Total debt service } \\
\text { (as \% of GNI) }\end{array}$ & $\begin{array}{c}0.045 \\
{[0.036]}\end{array}$ & $\begin{array}{c}0.056 \\
{[0.035]^{*}}\end{array}$ & $\begin{array}{c}0.047 \\
{[0.036]}\end{array}$ & $\begin{array}{c}0.186 \\
{[0.097]^{*}}\end{array}$ & $\begin{array}{c}0.261 \\
{[0.098]^{* * *}}\end{array}$ & $\begin{array}{c}0.191 \\
{[0.094]^{* *}}\end{array}$ \\
\hline Monetary Independence (MI) & $\begin{array}{c}-0.022 \\
{[0.015]}\end{array}$ & $\begin{array}{c}-0.03 \\
{[0.015]^{* *}}\end{array}$ & & $\begin{array}{c}0.028 \\
{[0.038]}\end{array}$ & $\begin{array}{c}0.079 \\
{[0.038]^{* *}}\end{array}$ & \\
\hline MI x reserves & $\begin{array}{c}-0.001 \\
{[0.094]}\end{array}$ & $\begin{array}{c}0.062 \\
{[0.095]}\end{array}$ & & $\begin{array}{c}-0.015 \\
{[0.232]}\end{array}$ & $\begin{array}{c}-0.232 \\
{[0.244]}\end{array}$ & \\
\hline Exchange Rate Stability (ERS) & $\begin{array}{c}0 \\
{[0.007]}\end{array}$ & & $\begin{array}{c}0.003 \\
{[0.007]}\end{array}$ & $\begin{array}{c}-0.086 \\
{[0.017]^{* * *}}\end{array}$ & & $\begin{array}{c}-0.091 \\
{[0.016]^{* * *}}\end{array}$ \\
\hline ERS $\mathrm{x}$ reserves & $\begin{array}{c}-0.046 \\
{[0.048]}\end{array}$ & & $\begin{array}{c}-0.041 \\
{[0.046]}\end{array}$ & $\begin{array}{c}0.213 \\
{[0.119]^{*}}\end{array}$ & & $\begin{array}{c}0.225 \\
{[0.112]^{* *}}\end{array}$ \\
\hline KA Openness & & $\begin{array}{c}-0.017 \\
{[0.008]^{* *}}\end{array}$ & $\begin{array}{c}-0.013 \\
{[0.008]^{*}}\end{array}$ & & $\begin{array}{c}-0.033 \\
{[0.021]}\end{array}$ & $\begin{array}{c}-0.051 \\
{[0.020]^{* * *}}\end{array}$ \\
\hline KAOPEN x reserves & & $\begin{array}{c}0.061 \\
{[0.045]} \\
\end{array}$ & $\begin{array}{c}0.041 \\
{[0.044]} \\
\end{array}$ & & $\begin{array}{c}-0.008 \\
{[0.122]} \\
\end{array}$ & $\begin{array}{c}0.062 \\
{[0.109]} \\
\end{array}$ \\
\hline Observations & 313 & 313 & 313 & 306 & 306 & 306 \\
\hline Adjusted R-squared & 0.21 & 0.22 & 0.21 & 0.76 & 0.74 & 0.77 \\
\hline
\end{tabular}

Note: The estimation models include the benchmark macroeconomic variables and other characteristic dummies though their estimation results are omitted to conserve space. 
Table 5: External Financing and Policy Orientation

\begin{tabular}{|c|c|c|c|c|c|c|c|c|c|c|c|c|}
\hline \multirow{3}{*}{$\begin{array}{l}\text { Dependent variable } \\
\text { (Policy Orientation) }\end{array}$} & \multicolumn{6}{|c|}{ Output Volatility } & \multicolumn{6}{|c|}{ Level of Inflation } \\
\hline & \multicolumn{2}{|c|}{$\begin{array}{l}\text { Mon. Indep. \& ERS } \\
\text { "Financially Closed" }\end{array}$} & \multicolumn{2}{|c|}{$\begin{array}{l}\text { Mon. Indep. \& KAO } \\
\text { "More Flexible Exch. R" }\end{array}$} & \multicolumn{2}{|c|}{$\begin{array}{l}\text { ERS \& KAO } \\
\text { “Currency Union” }\end{array}$} & \multicolumn{2}{|c|}{$\begin{array}{l}\text { Mon. Indep. \& ERS } \\
\text { "Financially Closed" }\end{array}$} & \multicolumn{2}{|c|}{$\begin{array}{l}\text { Mon. Indep. \& KAO } \\
\text { “More Flexible Exch. R” }\end{array}$} & \multicolumn{2}{|c|}{$\begin{array}{l}\text { ERS \& KAO } \\
\text { “Currency Union” }\end{array}$} \\
\hline & $(1)$ & (2) & (3) & (4) & (5) & (6) & (7) & (8) & (9) & $(10)$ & (11) & (12) \\
\hline Total Reserve/GDP & $\begin{array}{c}0.04 \\
{[0.014]^{* * *}}\end{array}$ & $\begin{array}{c}0.039 \\
{[0.014]^{* * *}}\end{array}$ & $\begin{array}{c}0.017 \\
{[0.014]}\end{array}$ & $\begin{array}{c}0.02 \\
{[0.014]}\end{array}$ & $\begin{array}{c}0.034 \\
{[0.014]^{* *}}\end{array}$ & $\begin{array}{c}0.032 \\
{[0.014]^{* *}}\end{array}$ & $\begin{array}{c}0.021 \\
{[0.039]}\end{array}$ & $\begin{array}{c}0.018 \\
{[0.038]}\end{array}$ & $\begin{array}{c}0.053 \\
{[0.036]}\end{array}$ & $\begin{array}{c}0.053 \\
{[0.037]}\end{array}$ & $\begin{array}{c}0.032 \\
{[0.036]}\end{array}$ & $\begin{array}{c}0.042 \\
{[0.037]}\end{array}$ \\
\hline Currency Crisis & $\begin{array}{c}0.005 \\
{[0.003]^{*}}\end{array}$ & $\begin{array}{c}0.006 \\
{[0.003]^{*}}\end{array}$ & $\begin{array}{c}0.005 \\
{[0.003]}\end{array}$ & $\begin{array}{c}0.005 \\
{[0.003]}\end{array}$ & $\begin{array}{c}0.006 \\
{[0.003]^{* *}}\end{array}$ & $\begin{array}{c}0.007 \\
{[0.003]^{* *}}\end{array}$ & $\begin{array}{c}0.049 \\
{[0.007]^{* * *}}\end{array}$ & $\begin{array}{c}0.048 \\
{[0.008]^{* * *}}\end{array}$ & $\begin{array}{c}0.043 \\
{[0.008]^{* * *}}\end{array}$ & $\begin{array}{c}0.043 \\
{[0.008]^{* * *}}\end{array}$ & $\begin{array}{c}0.042 \\
{[0.007]^{* * *}}\end{array}$ & $\begin{array}{c}0.04 \\
{[0.007]^{* * *}}\end{array}$ \\
\hline $\begin{array}{l}\text { (Policy Orientation) } \\
\text { (Policy Orientation) } \\
\text { x Reserves }\end{array}$ & $\begin{array}{c}0.001 \\
{[0.004]} \\
-0.033 \\
{[0.023]} \\
\end{array}$ & $\begin{array}{c}0.005 \\
{[0.007]} \\
-0.033 \\
{[0.023]} \\
\end{array}$ & $\begin{array}{c}-0.001 \\
{[0.005]} \\
0.03 \\
{[0.024]} \\
\end{array}$ & $\begin{array}{c}0.002 \\
{[0.008]} \\
0.027 \\
{[0.024]} \\
\end{array}$ & $\begin{array}{c}0.002 \\
{[0.005]} \\
-0.011 \\
{[0.023]} \\
\end{array}$ & $\begin{array}{l}-0.009 \\
{[0.008]} \\
-0.003 \\
{[0.023]} \\
\end{array}$ & $\begin{array}{c}0.011 \\
{[0.012]} \\
0.042 \\
{[0.060]} \\
\end{array}$ & $\begin{array}{c}-0.011 \\
{[0.018]} \\
0.05 \\
{[0.060]} \\
\end{array}$ & $\begin{array}{c}0.038 \\
{[0.014]^{* * *}} \\
-0.077 \\
{[0.062]} \\
\end{array}$ & $\begin{array}{c}0.027 \\
{[0.022]} \\
-0.073 \\
{[0.063]} \\
\end{array}$ & $\begin{array}{c}-0.044 \\
{[0.011]^{* * *}} \\
0.036 \\
{[0.056]} \\
\end{array}$ & $\begin{array}{c}-0.012 \\
{[0.019]} \\
0.021 \\
{[0.057]} \\
\end{array}$ \\
\hline Net FDI inflows/GDP & $\begin{array}{c}-0.082 \\
{[0.086]}\end{array}$ & $\begin{array}{c}-0.193 \\
{[0.086]^{* *}}\end{array}$ & $\begin{array}{c}0.015 \\
{[0.080]}\end{array}$ & $\begin{array}{c}0.023 \\
{[0.080]}\end{array}$ & $\begin{array}{c}-0.035 \\
{[0.111]}\end{array}$ & $\begin{array}{l}-0.028 \\
{[0.111]}\end{array}$ & $\begin{array}{l}-0.164 \\
{[0.236]}\end{array}$ & $\begin{array}{l}-0.136 \\
{[0.238]}\end{array}$ & $\begin{array}{c}-0.363 \\
{[0.225]^{10 \%}}\end{array}$ & $\begin{array}{c}-0.358 \\
{[0.227]^{11 \%}}\end{array}$ & $\begin{array}{c}-0.417 \\
{[0.298]}\end{array}$ & $\begin{array}{l}-0.385 \\
{[0.299]}\end{array}$ \\
\hline $\begin{array}{l}\text { Net FDI inflow } \\
\text { x (Policy Orientation) }\end{array}$ & $\begin{array}{c}0.161 \\
{[0.175]}\end{array}$ & $\begin{array}{c}0.321 \\
{[0.174]^{*}}\end{array}$ & $\begin{array}{l}-0.213 \\
{[0.186]}\end{array}$ & $\begin{array}{l}-0.175 \\
{[0.188]}\end{array}$ & $\begin{array}{c}0.019 \\
{[0.151]}\end{array}$ & $\begin{array}{c}-0.003 \\
{[0.151]}\end{array}$ & $\begin{array}{l}-0.304 \\
{[0.455]}\end{array}$ & $\begin{array}{l}-0.383 \\
{[0.459]}\end{array}$ & $\begin{array}{c}0.168 \\
{[0.494]}\end{array}$ & $\begin{array}{c}0.167 \\
{[0.500]}\end{array}$ & $\begin{array}{c}0.26 \\
{[0.375]}\end{array}$ & $\begin{array}{c}0.227 \\
{[0.377]}\end{array}$ \\
\hline Net portfolio inflows/GDP & $\begin{array}{c}0.189 \\
{[0.132]}\end{array}$ & $\begin{array}{c}-0.122 \\
{[0.130]}\end{array}$ & $\begin{array}{c}0.193 \\
{[0.090]^{* *}}\end{array}$ & $\begin{array}{c}0.2 \\
{[0.091]^{* *}}\end{array}$ & $\begin{array}{c}0.066 \\
{[0.104]}\end{array}$ & $\begin{array}{c}0.067 \\
{[0.103]}\end{array}$ & $\begin{array}{l}-0.272 \\
{[0.343]}\end{array}$ & $\begin{array}{l}-0.254 \\
{[0.344]}\end{array}$ & $\begin{array}{c}0.013 \\
{[0.337]}\end{array}$ & $\begin{array}{c}0.019 \\
{[0.340]}\end{array}$ & $\begin{array}{c}0.258 \\
{[0.494]}\end{array}$ & $\begin{array}{c}0.188 \\
{[0.496]}\end{array}$ \\
\hline $\begin{array}{l}\text { Net Portfolio inflow } \\
\quad \text { x (Policy Orientation) }\end{array}$ & $\begin{array}{c}-0.07 \\
{[0.175]}\end{array}$ & $\begin{array}{c}0.238 \\
{[0.173]}\end{array}$ & $\begin{array}{l}-0.345 \\
{[0.272]}\end{array}$ & $\begin{array}{l}-0.281 \\
{[0.283]}\end{array}$ & $\begin{array}{c}0.285 \\
{[0.186]^{12 \%}}\end{array}$ & $\begin{array}{c}0.332 \\
{[0.188]^{*}}\end{array}$ & $\begin{array}{c}1.265 \\
{[0.845]^{13 \%}}\end{array}$ & $\begin{array}{c}1.244 \\
{[0.844]}\end{array}$ & $\begin{array}{l}-0.206 \\
{[0.795]}\end{array}$ & $\begin{array}{l}-0.274 \\
{[0.816]}\end{array}$ & $\begin{array}{l}-0.426 \\
{[0.626]}\end{array}$ & $\begin{array}{c}-0.304 \\
{[0.636]}\end{array}$ \\
\hline Net 'other' inflows/GDP & $\begin{array}{c}0.055 \\
{[0.044]}\end{array}$ & $\begin{array}{c}0.063 \\
{[0.044]}\end{array}$ & $\begin{array}{c}0.03 \\
{[0.032]}\end{array}$ & $\begin{array}{c}0.032 \\
{[0.033]}\end{array}$ & $\begin{array}{c}0.083 \\
{[0.033]^{* *}}\end{array}$ & $\begin{array}{c}0.081 \\
{[0.033]^{* *}}\end{array}$ & $\begin{array}{l}-0.151 \\
{[0.113]}\end{array}$ & $\begin{array}{l}-0.167 \\
{[0.115]}\end{array}$ & $\begin{array}{c}0.112 \\
{[0.079]}\end{array}$ & $\begin{array}{c}0.109 \\
{[0.080]}\end{array}$ & $\begin{array}{c}0.02 \\
{[0.079]}\end{array}$ & $\begin{array}{c}0.008 \\
{[0.080]}\end{array}$ \\
\hline $\begin{array}{l}\text { Net 'Other' inflow } \\
\text { x (Policy Orientation) }\end{array}$ & $\begin{array}{c}0.017 \\
{[0.056]}\end{array}$ & $\begin{array}{c}0.012 \\
{[0.056]}\end{array}$ & $\begin{array}{c}0.093 \\
{[0.068]}\end{array}$ & $\begin{array}{c}0.08 \\
{[0.069]}\end{array}$ & $\begin{array}{c}-0.114 \\
{[0.067]^{*}}\end{array}$ & $\begin{array}{l}-0.092 \\
{[0.070]}\end{array}$ & $\begin{array}{c}0.304 \\
{[0.145]^{* *}}\end{array}$ & $\begin{array}{c}0.3 \\
{[0.147]^{* *}}\end{array}$ & $\begin{array}{c}-0.531 \\
{[0.183]^{* * *}}\end{array}$ & $\begin{array}{c}-0.513 \\
{[0.187]^{* * *}}\end{array}$ & $\begin{array}{c}0.08 \\
{[0.168]}\end{array}$ & $\begin{array}{c}0.071 \\
{[0.174]}\end{array}$ \\
\hline $\begin{array}{l}\text { Short-term Debt (as \% of } \\
\text { total external debt) } \\
\text { Short-term Debt } \\
\text { x (Policy Orientation) }\end{array}$ & $\begin{array}{c}-0.002 \\
{[0.018]}\end{array}$ & $\begin{array}{c}0.006 \\
{[0.021]} \\
-0.028 \\
{[0.030]}\end{array}$ & $\begin{array}{c}0.001 \\
{[0.017]}\end{array}$ & $\begin{array}{c}-0.004 \\
{[0.019]} \\
0.02 \\
{[0.032]}\end{array}$ & $\begin{array}{c}0.003 \\
{[0.017]}\end{array}$ & $\begin{array}{c}0.001 \\
{[0.019]} \\
-0.003 \\
{[0.031]}\end{array}$ & $\begin{array}{c}0.103 \\
{[0.047]^{* *}}\end{array}$ & $\begin{array}{c}0.089 \\
{[0.056]} \\
0.065 \\
{[0.078]}\end{array}$ & $\begin{array}{c}0.041 \\
{[0.043]}\end{array}$ & $\begin{array}{c}0.03 \\
{[0.048]} \\
0.032 \\
{[0.080]}\end{array}$ & $\begin{array}{c}0.086 \\
{[0.044]^{*}}\end{array}$ & $\begin{array}{c}0.116 \\
{[0.049]^{* *}} \\
-0.081 \\
{[0.078]}\end{array}$ \\
\hline $\begin{array}{l}\text { Total debt service } \\
\text { (as \% of GNI) } \\
\text { Total debt service } \\
\text { x (Policy Orientation) }\end{array}$ & $\begin{array}{c}0.052 \\
{[0.036]}\end{array}$ & $\begin{array}{c}0.074 \\
{[0.044]^{*}} \\
-0.049 \\
{[0.067]} \\
\end{array}$ & $\begin{array}{c}0.066 \\
{[0.035]^{*}}\end{array}$ & $\begin{array}{c}0.093 \\
{[0.041]^{* *}} \\
-0.097 \\
{[0.079]}\end{array}$ & $\begin{array}{c}0.053 \\
{[0.035]}\end{array}$ & $\begin{array}{c}0.003 \\
{[0.042]} \\
0.178 \\
{[0.073]^{* *}}\end{array}$ & $\begin{array}{c}0.204 \\
{[0.099]^{* *}}\end{array}$ & $\begin{array}{c}0.097 \\
{[0.121]} \\
0.246 \\
{[0.177]} \\
\end{array}$ & $\begin{array}{c}0.201 \\
{[0.097]^{* *}}\end{array}$ & $\begin{array}{c}0.18 \\
{[0.109]^{*}} \\
0.099 \\
{[0.204]} \\
\end{array}$ & $\begin{array}{c}0.261 \\
{[0.095]^{* * *}}\end{array}$ & $\begin{array}{c}0.374 \\
{[0.116]^{* * *}} \\
-0.293 \\
{[0.186]^{11 \%}} \\
\end{array}$ \\
\hline Observations & 313 & 313 & 313 & 313 & 313 & 313 & 306 & 306 & 306 & 306 & 306 & 306 \\
\hline Adjusted R-squared & 0.2 & 0.24 & 0.21 & 0.21 & 0.21 & 0.21 & 0.73 & 0.73 & 0.74 & 0.73 & 0.75 & 0.75 \\
\hline
\end{tabular}


Table 6: Trilemma Configurations and External Financing of Major EMG Countries as of 2007

\begin{tabular}{|c|c|c|c|c|c|c|c|c|c|c|c|c|c|c|c|c|}
\hline & $\begin{array}{l}\text { Financial } \\
\text { Develop. }\end{array}$ & \multicolumn{8}{|c|}{ Trilemma Indexes } & \multicolumn{6}{|c|}{ External Finances } & \multirow{2}{*}{$\begin{array}{c}\text { Swap } \\
\text { /IMF } \\
\text { (\$ bill.)** }\end{array}$} \\
\hline & PCGDP* & IR & dIR & MI & $\mathrm{dMI}$ & ERS & dERS & $\begin{array}{c}\text { KA- } \\
\text { OPEN }\end{array}$ & dKAO & FDI & $\mathrm{dFDI}$ & Port. & dPort & Other & dOther & \\
\hline Argentina & $11.4 \%$ & $17.2 \%$ & $4.5 \%$ & 0.74 & 0.49 & 0.61 & 0.29 & 0.24 & -0.08 & $1.9 \%$ & $0.1 \%$ & $2.7 \%$ & $5.3 \%$ & $-3.0 \%$ & $3.6 \%$ & \\
\hline Brazil & $32.9 \%$ & $13.6 \%$ & $6.0 \%$ & 0.12 & -0.36 & 0.24 & 0.05 & 0.64 & 0.06 & $2.1 \%$ & $0.8 \%$ & $3.7 \%$ & $3.5 \%$ & $1.0 \%$ & $2.1 \%$ & 30 (FR) \\
\hline Chile & $74.5 \%$ & $10.3 \%$ & $-7.4 \%$ & 0.96 & 0.74 & 0.35 & 0.06 & 1.00 & 0.07 & $6.5 \%$ & $2.5 \%$ & $-9.6 \%$ & $-5.7 \%$ & $-2.9 \%$ & $-2.8 \%$ & \\
\hline China & $135.5 \%$ & $46.6 \%$ & $15.7 \%$ & 0.50 & -0.02 & 0.75 & -0.22 & 0.15 & 0.00 & $3.7 \%$ & $0.9 \%$ & $0.6 \%$ & $0.9 \%$ & $-2.1 \%$ & $-2.5 \%$ & \\
\hline Colombia & $24.5 \%$ & $10.2 \%$ & $-1.5 \%$ & 0.83 & 0.24 & 0.17 & -0.16 & 0.39 & 0.10 & $4.7 \%$ & $1.9 \%$ & $0.5 \%$ & $1.4 \%$ & $0.8 \%$ & $0.6 \%$ & \\
\hline Czech Rep. & $37.3 \%$ & $19.7 \%$ & $-6.6 \%$ & 0.16 & -0.34 & 0.38 & 0.00 & 0.81 & -0.15 & $4.7 \%$ & $-1.1 \%$ & $-1.5 \%$ & $-0.5 \%$ & $-0.3 \%$ & $-2.7 \%$ & \\
\hline Egypt & $52.6 \%$ & $23.6 \%$ & $3.6 \%$ & 0.50 & 0.18 & 0.64 & -0.11 & 1.00 & 0.06 & $8.5 \%$ & $5.0 \%$ & $-2.8 \%$ & $-3.3 \%$ & $-3.4 \%$ & $2.7 \%$ & \\
\hline Hong Kong & $138.7 \%$ & $73.9 \%$ & $2.8 \%$ & 0.10 & -0.11 & 0.79 & -0.21 & 1.00 & 0.00 & $-3.3 \%$ & $-2.7 \%$ & $-1.3 \%$ & $18.8 \%$ & $-7.7 \%$ & $-12.8 \%$ & \\
\hline Hungary & $51.4 \%$ & $17.4 \%$ & $1.0 \%$ & 0.86 & 0.24 & 0.38 & 0.01 & 0.81 & -0.07 & $3.2 \%$ & $-0.1 \%$ & $-1.7 \%$ & $-6.3 \%$ & $4.8 \%$ & $3.4 \%$ & 25 (IMF) \\
\hline India & $40.2 \%$ & $24.3 \%$ & $7.1 \%$ & 0.37 & 0.21 & 0.35 & -0.14 & 0.15 & 0.00 & & & & & & & \\
\hline Indonesia & $22.7 \%$ & $12.7 \%$ & $-1.1 \%$ & 0.32 & -0.02 & 0.34 & 0.04 & 0.69 & 0.00 & $0.5 \%$ & $0.0 \%$ & $1.3 \%$ & $0.0 \%$ & $-1.1 \%$ & $0.9 \%$ & \\
\hline Israel & $87.5 \%$ & $17.4 \%$ & $-4.4 \%$ & 0.55 & 0.20 & 0.28 & -0.11 & 1.00 & 0.02 & $1.6 \%$ & $1.3 \%$ & $0.2 \%$ & $2.3 \%$ & $-3.0 \%$ & $-0.1 \%$ & \\
\hline Korea & $112.5 \%$ & $27.0 \%$ & $1.0 \%$ & 0.93 & 0.56 & 0.40 & 0.06 & 0.39 & 0.00 & $-1.4 \%$ & $-1.5 \%$ & $-2.5 \%$ & $-3.0 \%$ & $4.3 \%$ & $3.0 \%$ & $30(\mathrm{FR}) * * *$ \\
\hline Lithuania & $37.2 \%$ & $19.4 \%$ & $2.4 \%$ & 0.11 & -0.12 & 0.71 & 0.18 & 1.00 & 0.00 & $3.7 \%$ & $0.5 \%$ & $-0.6 \%$ & $-0.7 \%$ & $13.3 \%$ & $7.4 \%$ & \\
\hline Malaysia & $110.2 \%$ & $54.0 \%$ & $6.8 \%$ & 0.50 & 0.06 & 0.44 & -0.46 & 0.39 & 0.00 & $-1.4 \%$ & $-2.5 \%$ & $3.0 \%$ & $1.8 \%$ & $-7.5 \%$ & $-1.9 \%$ & \\
\hline Mexico & $19.5 \%$ & $8.5 \%$ & $-0.5 \%$ & 0.90 & 0.48 & 0.42 & 0.09 & 0.69 & 0.10 & $2.1 \%$ & $-0.2 \%$ & $1.7 \%$ & $1.1 \%$ & $-1.4 \%$ & $-0.8 \%$ & 30 (FR) \\
\hline Pakistan & $26.5 \%$ & $9.8 \%$ & $-1.5 \%$ & 0.51 & 0.24 & 0.76 & -0.06 & 0.15 & 0.00 & $3.6 \%$ & $2.0 \%$ & $1.5 \%$ & $0.8 \%$ & $1.9 \%$ & $2.9 \%$ & 10 (IMF) \\
\hline Peru & $17.3 \%$ & $25.1 \%$ & $7.6 \%$ & 0.93 & 0.76 & 0.50 & -0.05 & 1.00 & 0.00 & $4.9 \%$ & $1.9 \%$ & $3.1 \%$ & $2.4 \%$ & $0.5 \%$ & $2.4 \%$ & \\
\hline Philippines & $29.0 \%$ & $21.0 \%$ & $1.6 \%$ & 0.10 & -0.18 & 0.37 & -0.12 & 0.45 & 0.00 & $-0.4 \%$ & $-1.6 \%$ & $3.1 \%$ & $1.5 \%$ & $-0.5 \%$ & $2.0 \%$ & \\
\hline Poland & $28.6 \%$ & $14.9 \%$ & $0.4 \%$ & 0.13 & -0.20 & 0.37 & 0.08 & 0.45 & 0.00 & $4.3 \%$ & $1.5 \%$ & $-1.2 \%$ & $-3.0 \%$ & $6.9 \%$ & $7.4 \%$ & \\
\hline Russian & $26.2 \%$ & $36.1 \%$ & $14.8 \%$ & 0.80 & 0.35 & 0.48 & -0.07 & 0.39 & 0.00 & $0.7 \%$ & $0.5 \%$ & $0.5 \%$ & $0.5 \%$ & $6.2 \%$ & $6.1 \%$ & \\
\hline Singapore & $96.1 \%$ & $101.2 \%$ & $0.9 \%$ & 0.52 & -0.03 & 0.51 & 0.00 & 1.00 & 0.00 & $7.3 \%$ & $-1.8 \%$ & $-10.3 \%$ & $-0.5 \%$ & $-8.4 \%$ & $4.5 \%$ & 30 (FR) \\
\hline Slovak & $35.9 \%$ & $24.0 \%$ & $-9.0 \%$ & 0.73 & 0.28 & 0.39 & -0.03 & 0.76 & 0.25 & $4.0 \%$ & $-3.5 \%$ & $-1.0 \%$ & $-1.7 \%$ & $6.3 \%$ & $3.8 \%$ & \\
\hline S. Africa & $103.6 \%$ & $10.5 \%$ & $3.2 \%$ & 0.97 & 0.43 & 0.29 & 0.12 & 0.15 & 0.00 & $1.0 \%$ & $0.7 \%$ & $4.2 \%$ & $1.7 \%$ & $2.8 \%$ & $3.0 \%$ & \\
\hline Thailand & $86.9 \%$ & $34.8 \%$ & $4.4 \%$ & 0.19 & 0.09 & 0.52 & 0.11 & 0.15 & -0.24 & $3.0 \%$ & $-0.5 \%$ & $-2.8 \%$ & $-3.9 \%$ & $-1.4 \%$ & $1.6 \%$ & \\
\hline Turkey & $28.8 \%$ & $11.1 \%$ & $-3.2 \%$ & 0.02 & -0.47 & 0.31 & 0.12 & 0.15 & 0.00 & $3.1 \%$ & $1.7 \%$ & $0.1 \%$ & $-1.2 \%$ & $4.2 \%$ & $2.0 \%$ & \\
\hline Venezuela & $13.4 \%$ & $10.6 \%$ & $-8.5 \%$ & 0.94 & 0.64 & 1.00 & 0.19 & 0.31 & -0.06 & $-0.7 \%$ & $-0.9 \%$ & $1.8 \%$ & $3.8 \%$ & $-11.1 \%$ & $-3.3 \%$ & \\
\hline
\end{tabular}

Notes: $d X$ refers to a change of the variable $X$ compared to the 2002-06 period.

* PCGDP is as of 2006 or 2005 if the figure for 2006 is unavailable.

** “Swap/IMF” refer to the amount of swap lines provided by the U.S. Federal Reserve on Oct. 29, 2008 as well as the loans provided by IMF as of Mach 2009. The information on Fed swap lines is based on Obstfeld et al. (2009)

*** In December 2008, China and Japan also agreed to provide Korea with swap lines of \$28 billion and \$20 billion, respectively. 


\section{Figure 1: The Trilemma and International Reserves Configurations over Time}

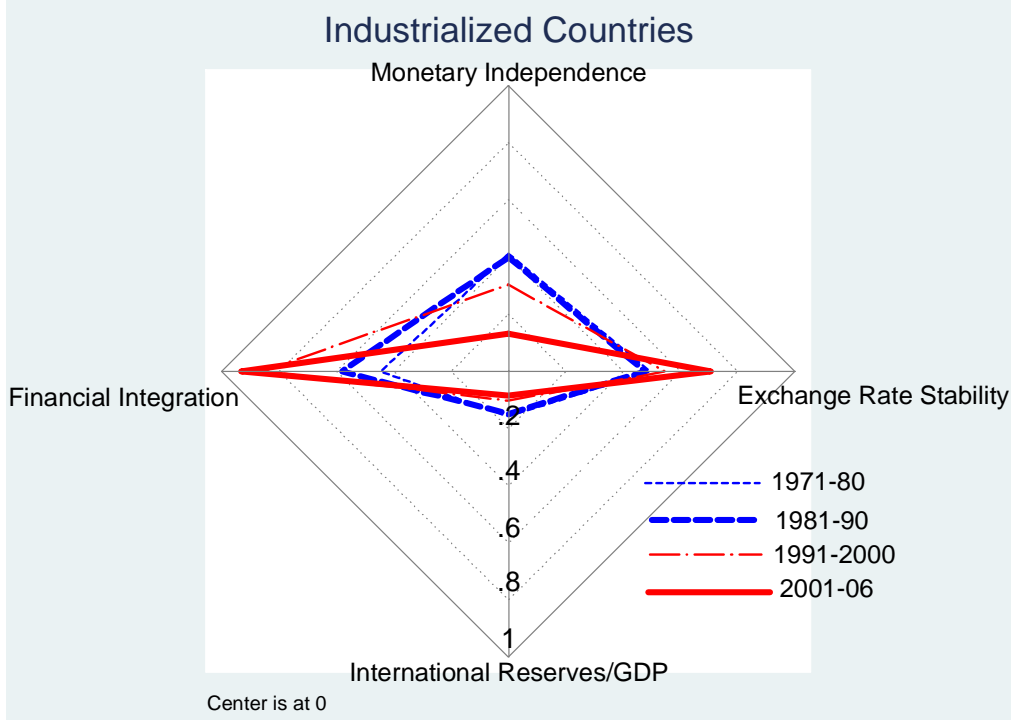

Non-Euro Industrialized Countries

$$
\text { Monetary Independence }
$$

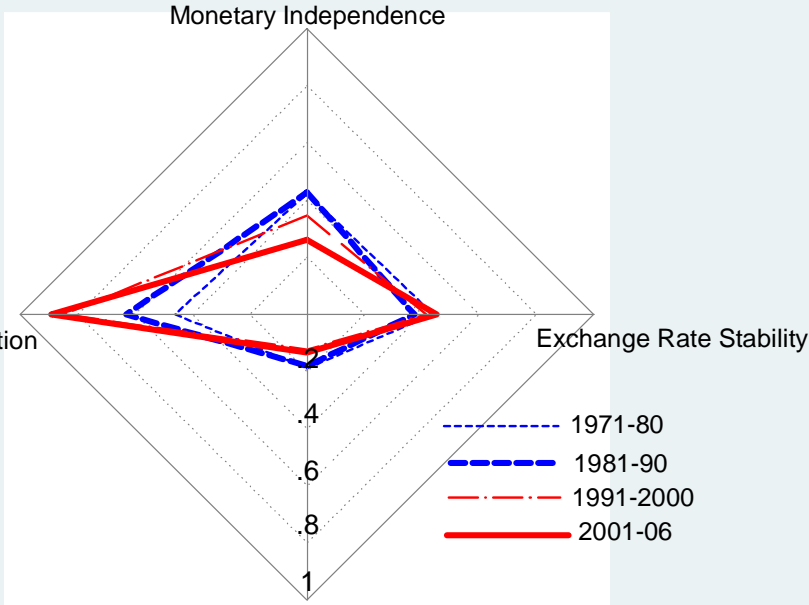

Center is at 0

International Reserves/GDP

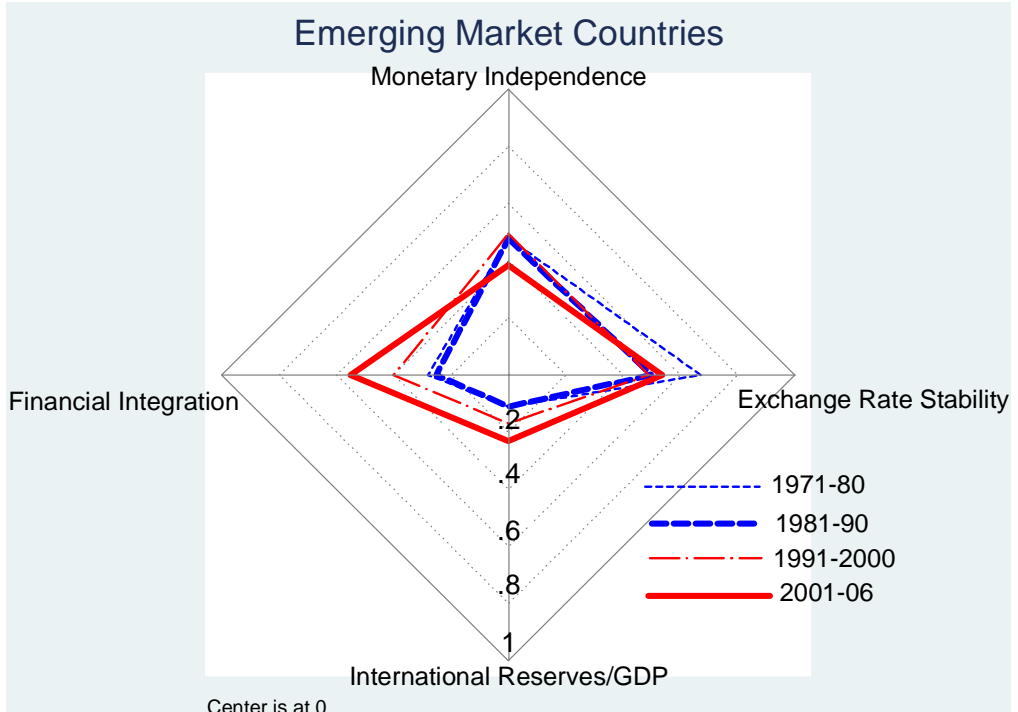

Non-Emerging Market Developing Countries

Monetary Independence

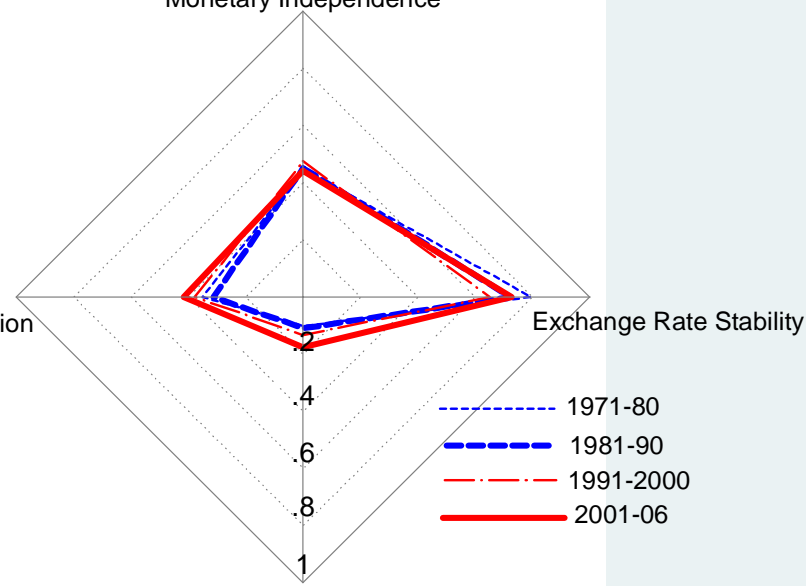

Center is at 0 
Figure 2: The Trilemma and International Reserve Configurations over Time: Regional Patterns for Developing Countries

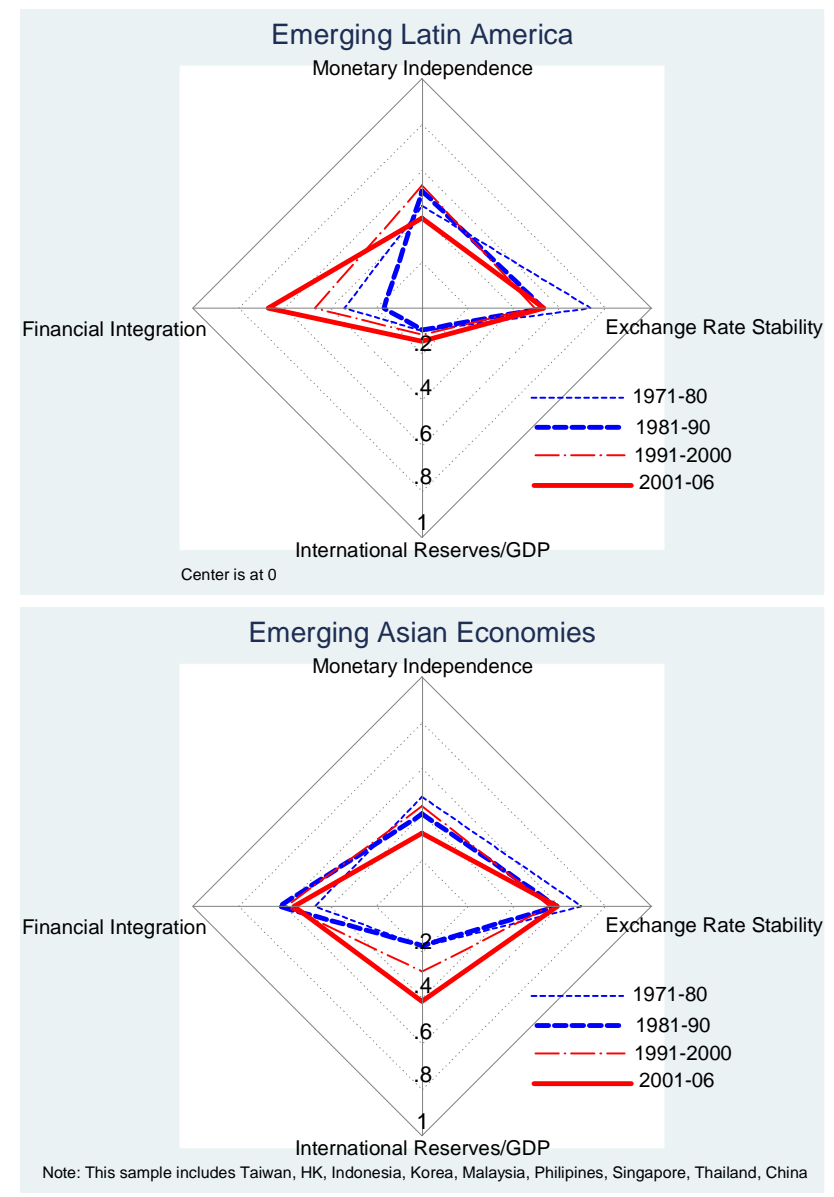

NOTES: "Emerging Asian Economies” include China, Hong Kong, Indonesia, Korea, Malaysia, Philippines, Singapore, Taiwan, and Thailand. "Emerging Latin America" includes Argentina, Brazil, Chile, Colombia, Ecuador, Jamaica, Mexico, Peru, Trinidad and Tobago, and Venezuela. 
Figure 3: The Evolution of Trilemma Indexes

(a) Industrialized Countries

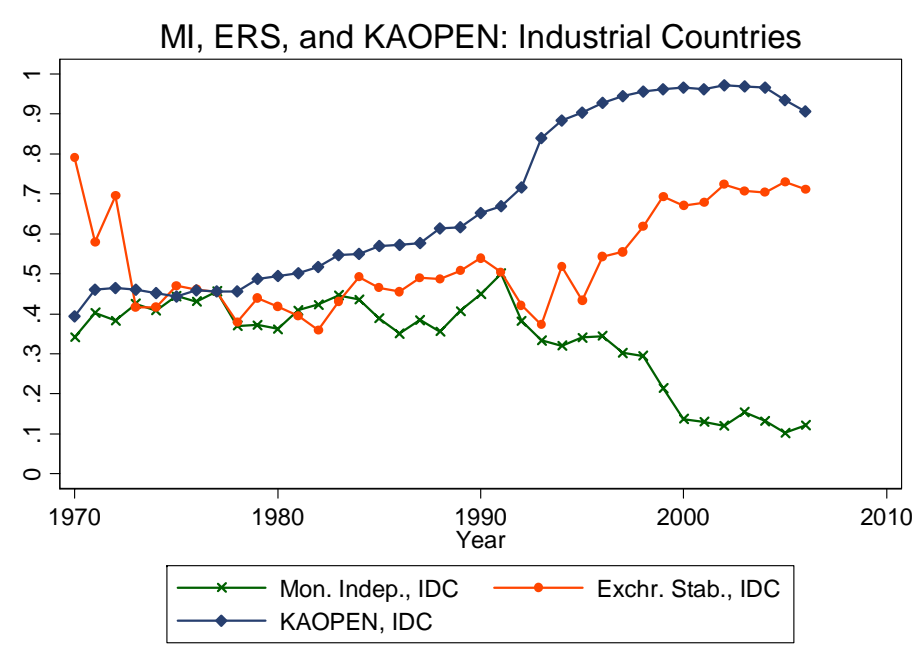

(b) Emerging Market Countries

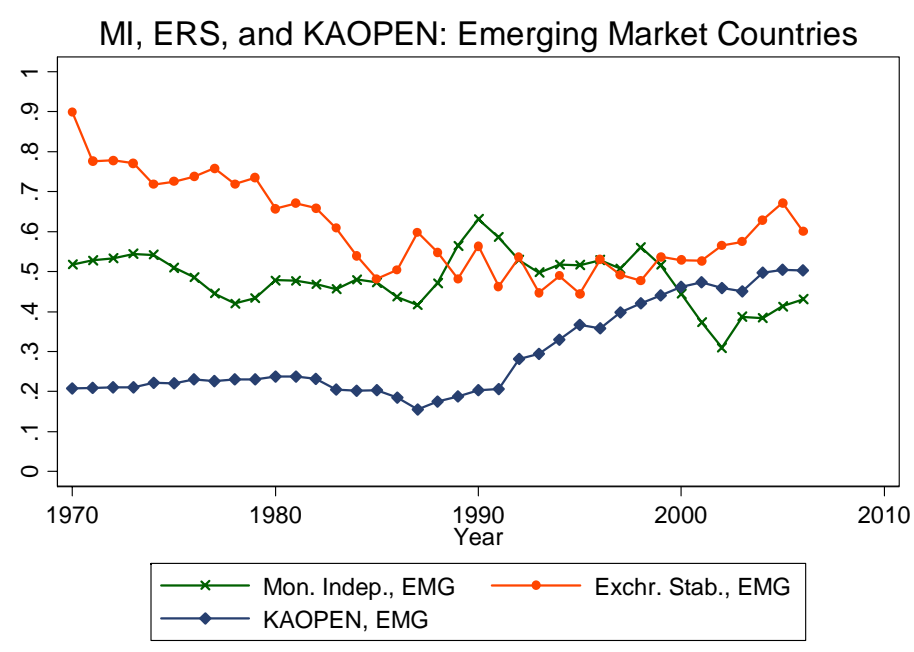

(c) Non-Emerging Market Developing Countries

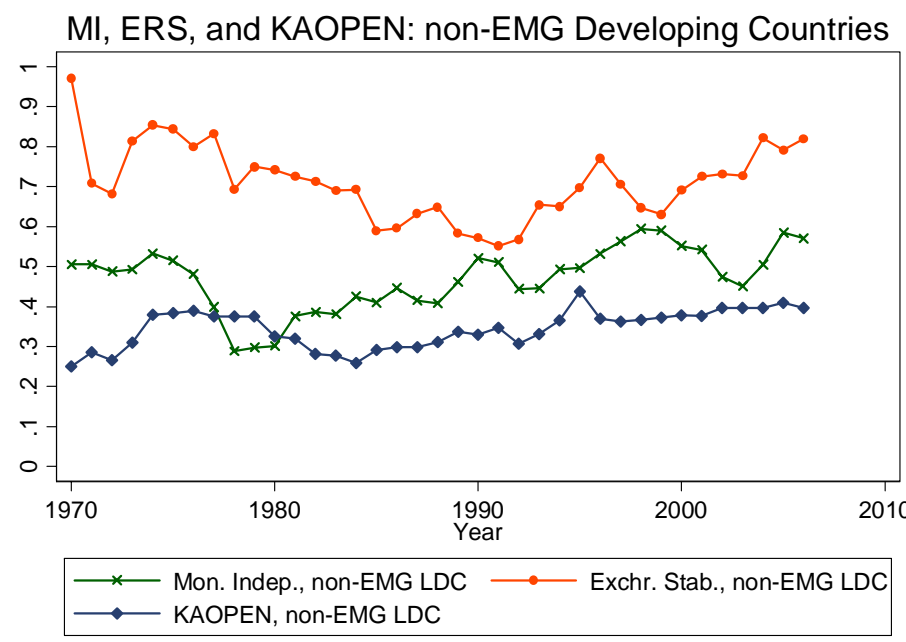


Figure 4: Non-linear Effect of Exchange Rate Stability - 1992-96 vs. 2002-06

(a) Asian EMG

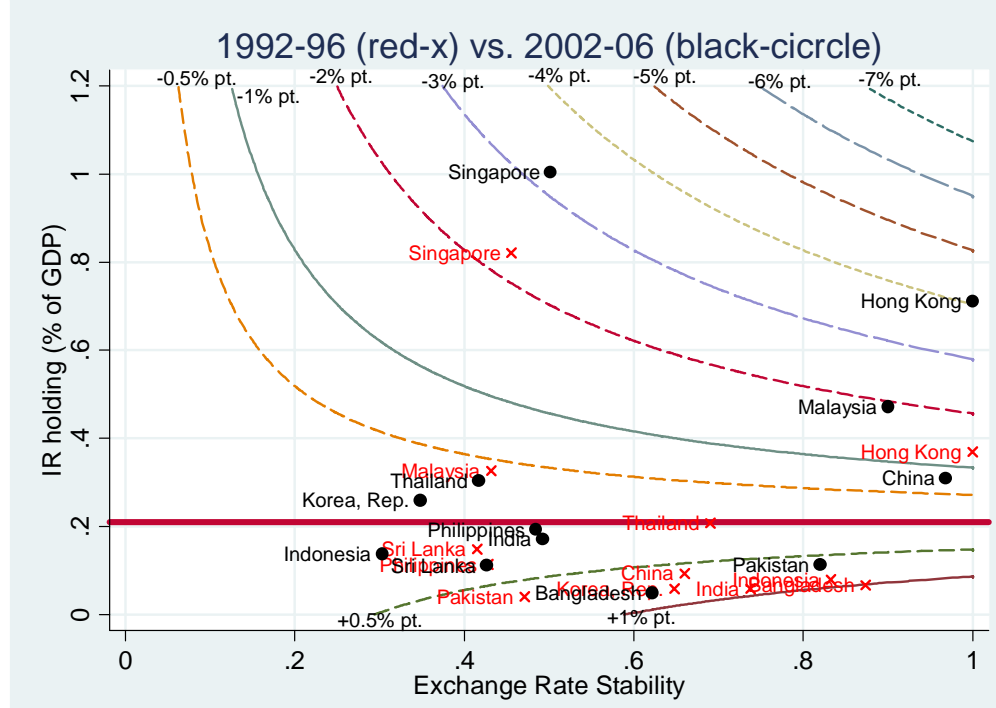

(b) Latin American EMG

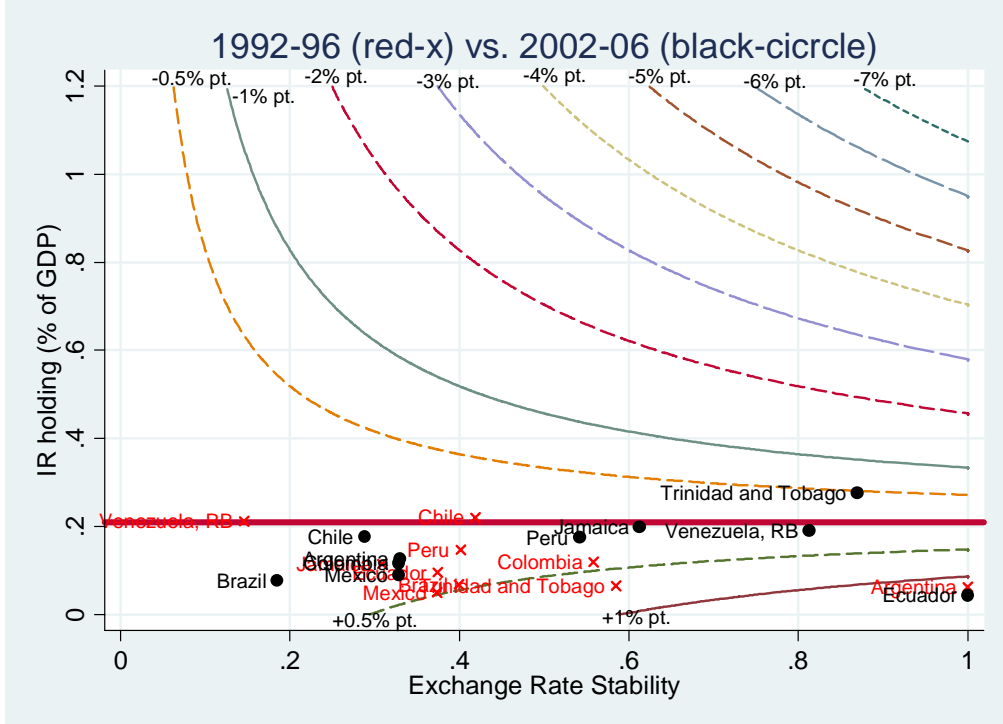

(c) EMG excluding Asia and Latin America

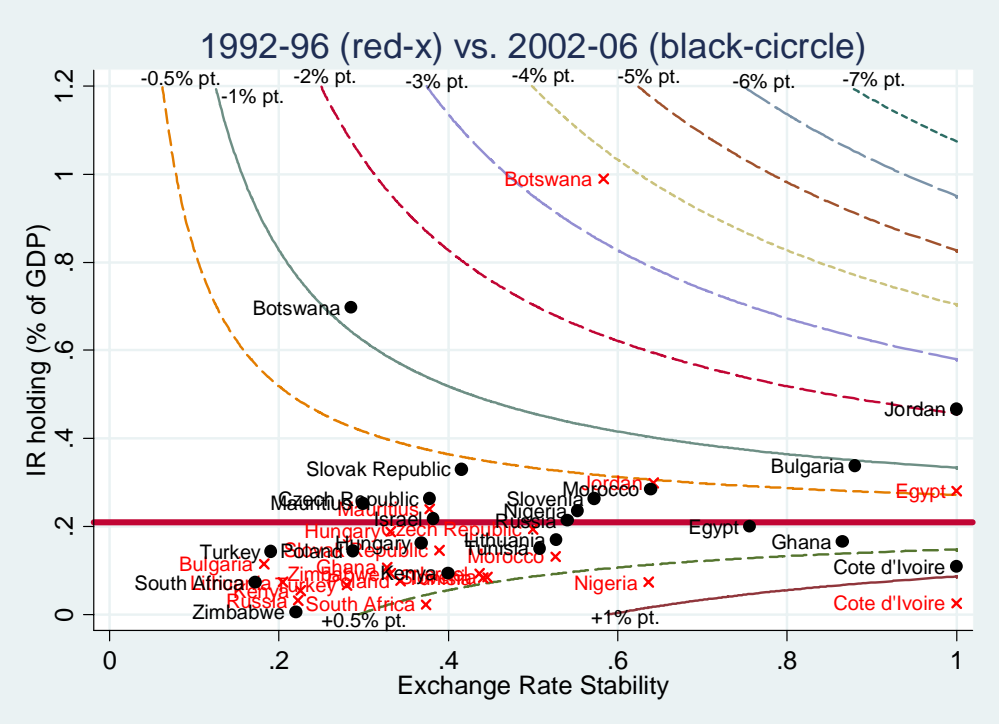


Figure 5: MI-KAO vs. Exchange Rate Stability

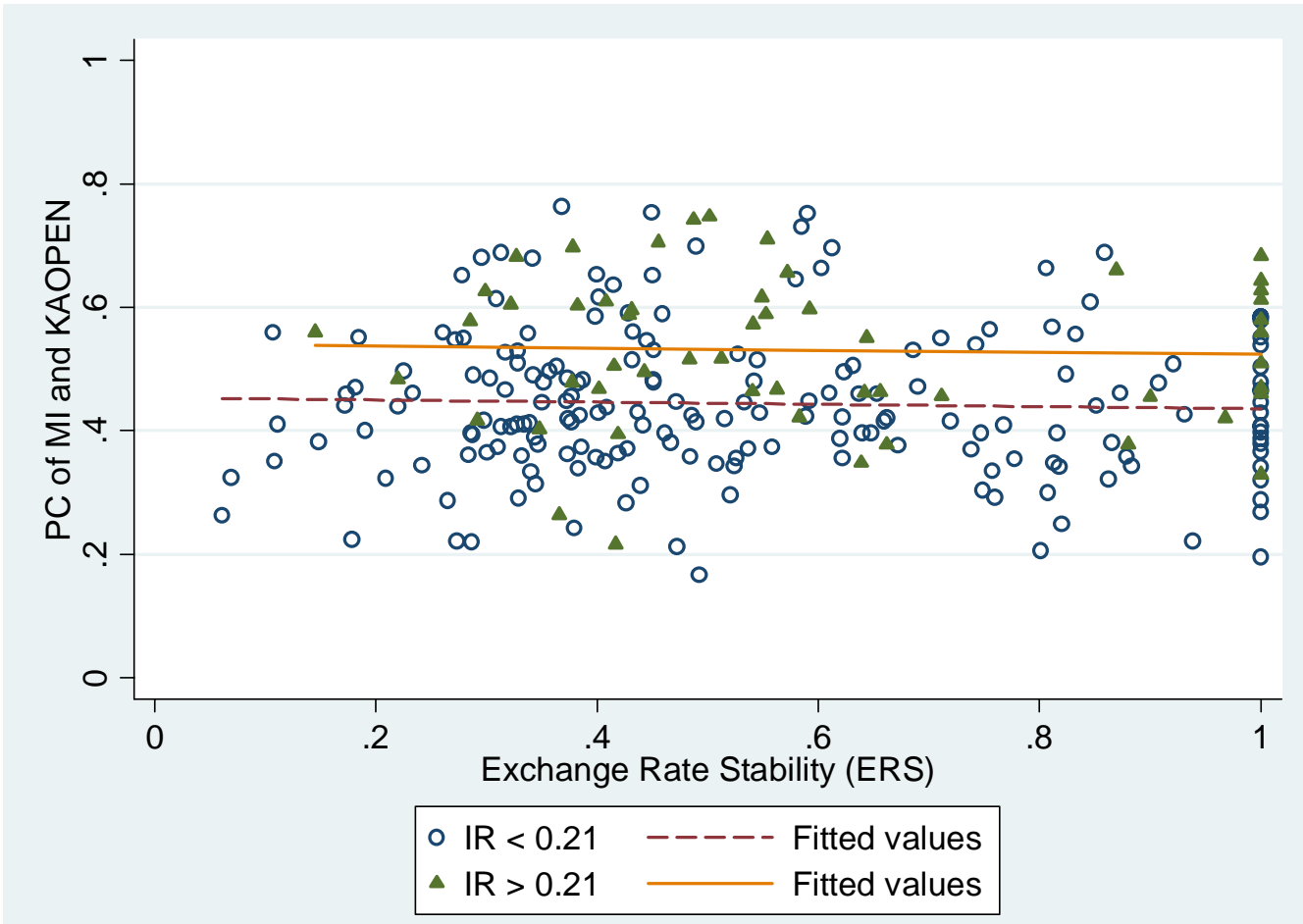

Figure 6: Trilemma Indexes and IR Holding for Asian EMG and China

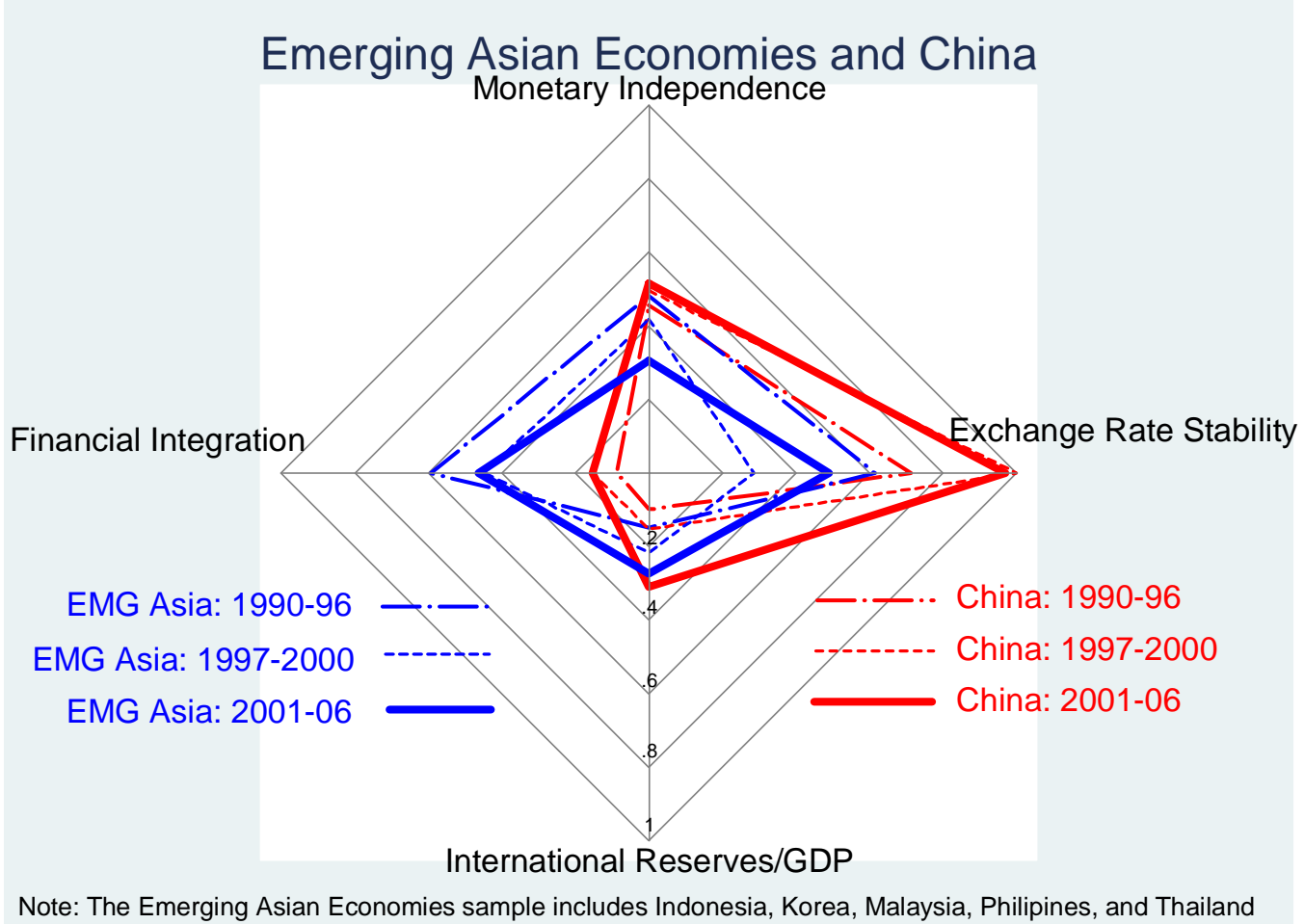

